BAKER, JENNIFER BAUK, M.S. An Investigation of the Motivations for Second-hand Clothing Donation and Purchase (2011).

Directed by Dr. Jennifer Yurchisin. 140 pp.

The purpose of this research was to investigate the motives of second-hand clothing consumers who both purchase from and donate to the retail outlet associated with one charitable organization. More specifically, individuals' motivations for donating clothing were compared to their motivations for purchasing second-hand clothing from the same location using the hedonic/utilitarian framework. Furthermore, the demographic and social psychological factors affecting individuals' motivations for donating to and purchasing second-hand clothing from a charitable organization's retail outlet were examined. Little research has been conducted in the area of clothing donation and second-hand clothing purchase, and no research could be located in which both processes were examined in the same study. The present study aimed to see if there is a connection among the two processes. By considering both processes within one retail context, a more complete understanding of the whole consumption process, from problem recognition through disposal, is obtained.

Qualitative research using in-depth interviews was used for this project. Due to the lack of previous research in this area, the research was exploratory in nature. Because the purpose of this study was to gain a deeper understanding of the complex relationship that may exist between consumers' motivations for donating clothing to and purchasing clothing from one retail location, face-to-face in-depth interviews were used to uncover information about the clothing donation and second-hand clothing consumption experience of participants. Open-ended questions pertaining to the research objectives 
were developed so that the participants could divulge as much information about their experiences as possible. Eighteen members of the Junior League of Winston-Salem who had donated second-hand clothing to and purchased second-hand clothing from the Rummage Sale were purposively selected. Each interview lasted approximately 30 to 90 minutes, was audio-recorded, and was transcribed verbatim. Each interview transcript was read in its entirety several times, and a thematic analysis was performed.

The majority of participants were categorized as either treat seekers (hedonic purchasers/hedonic donors) or rational helpers (utilitarian purchasers/hedonic donors). Only two participants were categorized as reward seekers (hedonic purchasers/utilitarian donors), and two participants were categorized as planners (utilitarian purchasers/utilitarian donors). Important demographic characteristics that influenced purchase and donation behavior included age of participants and the age of children living at home. Important social psychographic characteristics that influenced purchase and donation behavior included need for uniqueness, individuality, creativity, price consciousness, need for convenience, clothing attachment, and voluntary simplification. Additional themes related to the impact of liminality and organizational involvement on donation and purchase behavior also emerged. Limitations to this research and ideas for further research were discussed. 


\title{
AN INVESTIGATION OF THE MOTIVATIONS FOR SECOND-HAND CLOTHING DONATION AND PURCHASE
}

\author{
By \\ Jennifer Bauk Baker

\begin{abstract}
A Thesis Submitted to
the Faculty of The Graduate School at The University of North Carolina at Greensboro

in Partial Fulfillment

of the Requirements for the Degree of Master of Science
\end{abstract}

\section{Greensboro \\ 2011}

Approved by

Committee Chair 


\section{APPROVAL PAGE}

This thesis has been approved by the following committee of the Faculty of The Graduate School at The University of North Carolina at Greensboro.

Committee Chair

Committee Members

Date of Acceptance by Committee

Date of Final Oral Examination 


\section{ACKNOWLEDGEMENTS}

I would like to give special thanks to Dr. Jennifer Yurchisin, my thesis advisor, for her help and guidance during this research project. With her time and effort, she was able to give me the encouragement to complete my thesis.

Additionally, I would like to thank my committee members, Dr. Nancy Hodges

and Dr. Tu Watchravesringkan. Their support and assistance was also appreciated through this process.

I would also like to recognize and thank the Junior League of Winston-Salem for allowing me to collect data and observe the Rummage Sale.

Special thanks to my professors and fellow students in the Consumer, Apparel, and Retail Studies department at UNC-Greensboro who taught and encouraged me throughout my graduate studies.

I am especially grateful for my family for their love and support through my graduate studies. In particular, my husband, Patrick Baker, and my sister, Kathryn Bauk, have been important motivators throughout my tenure as a graduate student. 


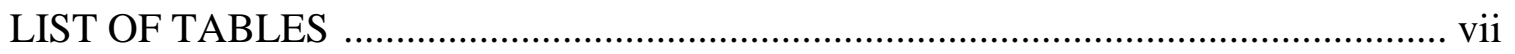

LIST OF FIGURES ......................................................................................

\section{CHAPTER}

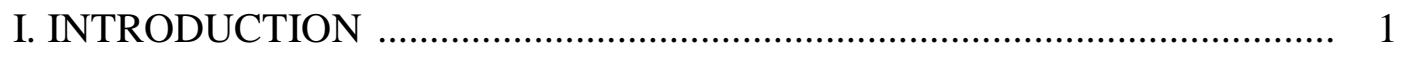

Statement of the Problem ....................................................................... 1

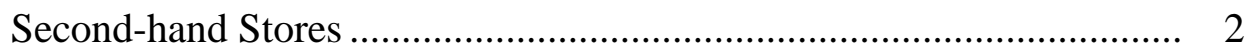

Types of Second-hand Clothing ........................................................... 3

Consumption of Second-hand Clothing …………………………........ 4

Hedonic and Utilitarian Shopping Motivations...................................... 7

Clothing Disposition .......................................................................... 10

Hedonic and Utilitarian Donation Motivation ....................................... 11

The Relationship between Purchasing and Donating Motivation ........... 14

Rummage Sale .................................................................................... 15

Research Purpose and Objectives ................................................................ 17

Significance of the Study ...................................................................... 19

Organization of the Study ........................................................................ 20

Definition of Key Terms ........................................................................... 20

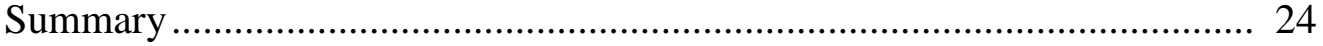

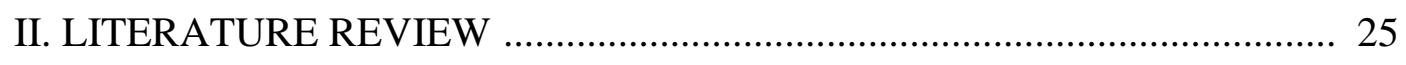

The Engel, Kollat, and Blackwell Consumer Decision-Making

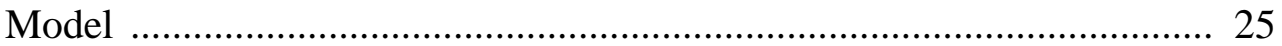

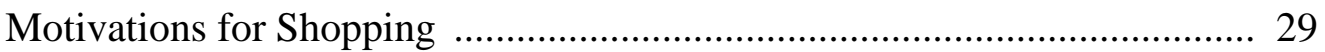

Cognitive Social Psychological Perspective_Field Theory ................. 29

Hedonic Versus Utilitarian Shopping Motivation ................................. 30

The Second-hand Clothing Market ……………………………………..... 36

Types of Second-hand Clothing Stores ……………………………... 36

Hedonic and Utilitarian Motivation for Purchasing

Second-hand Clothing ................................................................. 36

The Clothing Disposition Process …………………………........................ 40

Methods of Clothing Disposition ......................................................... 41

Divestment Rituals during Disposition ............................................... 44

Motivations for Donating Clothing to Non-Profit Thrift Stores ................... 47

The Relationship between Purchase and Donation ....................................... 51 


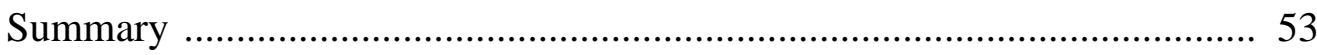

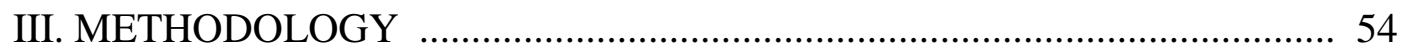

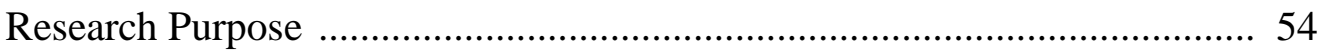

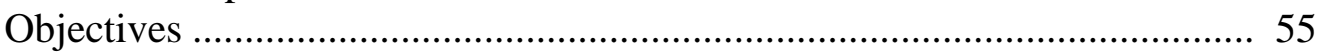

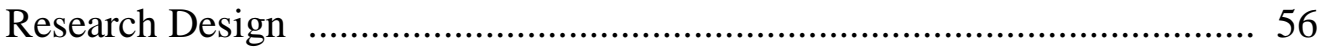

Participant Selection and Data Collection ……………................................. 57

Data Analysis ................................................................................. 59

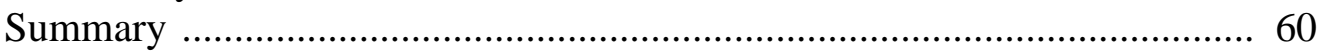

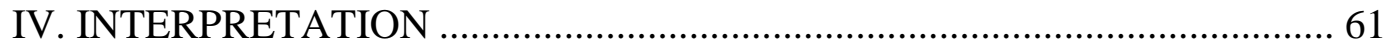

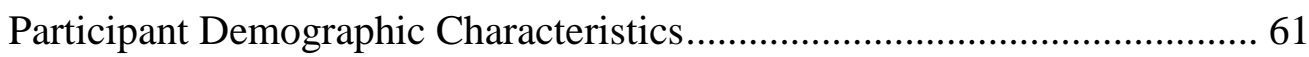

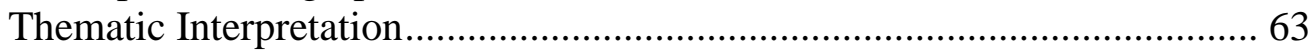

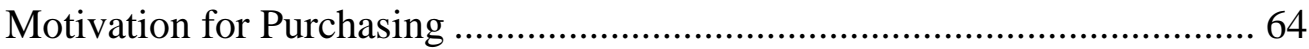

Hedonic Purchasing-Emotional Thrifters …………………………....... 64

Utilitarian Purchasing-Specific Thrifters ………………..................... 69

Factors Influencing Motivation for Purchasing ............................................. 74

Demographic Characteristics ........................................................... 74

Age

Mothers of Young Children ...................................................... 74

Social Psychological Characteristics .................................................. 76

Need for Uniqueness.............................................................. 76

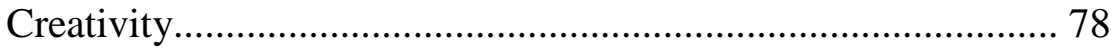

Price Consciousness ............................................................... 79

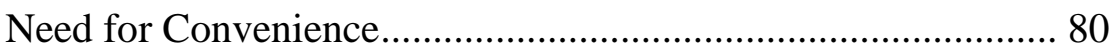

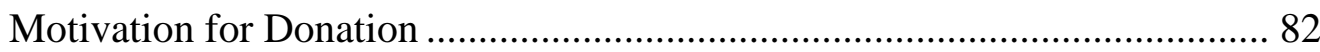

Hedonic Donating-Feel-Good Donors ............................................ 82

Utilitarian Donating-Methodical Donors ........................................... 85

Factors Influencing Motivation for Donating .............................................. 88

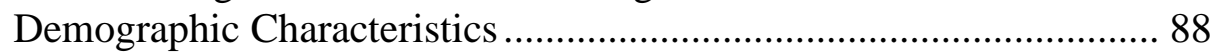

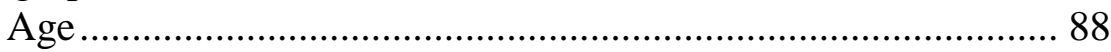

Social Psychological Characteristics ……………………………..... 89

Clothing Attachment ................................................................. 89

Voluntary Simplification .......................................................... 92

Connection between Motivations and Factors Influencing

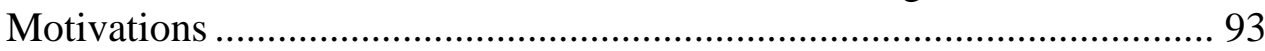

Hedonic Purchasers and Donors-Treat Seekers .............................. 93

Utilitarian Purchasers and Donors-Planners .................................... 96

Hedonic Purchasers and Utilitarian Donors—Reward Seekers......... 97

Utilitarian Purchasers and Hedonic Donors-Rational Helpers........ 99

Additional Themes 


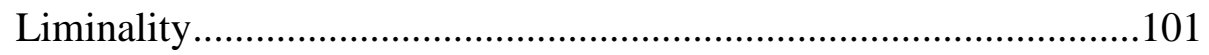

The Impact of Organizational Involvement ......................................103

Summary

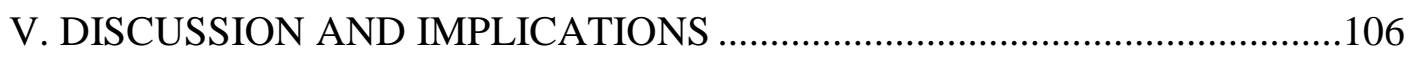

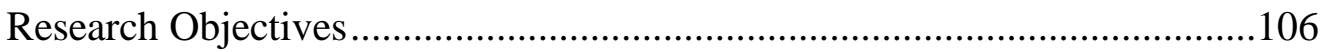

Second-hand Clothing Purchasers ................................................................107

Similarities in Hedonic Purchasers' Motivations ............................107

Similarities in Utilitarian Purchasers' Motivations...........................109

Demographic and Social Psychological Similarities of

Hedonic Purchasers........................................................................111

Demographic and Social Psychological Similarities of

Utilitarian Purchasers ................................................................112

Second-hand Clothing Donors ......................................................................... 114

Similarities in Hedonic Donors' Motivations .....................................114

Similarities in Utilitarian Donors' Motivations .................................115

Demographic and Social Psychological Similarities of

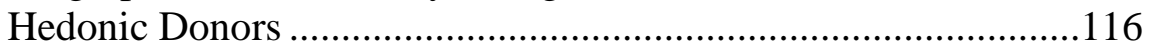

Demographic and Social Psychological Similarities of

Utilitarian Donors .........................................................................117

Relationship between Motivations and Factors Influencing

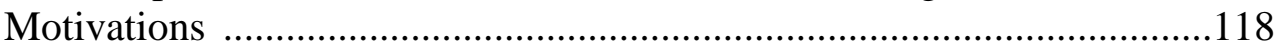

Additional Findings ..................................................................................121

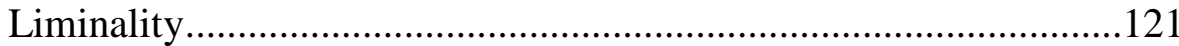

Managerial Implications and Impact on Junior League....................122

Limitations and Future Research ...................................................................123

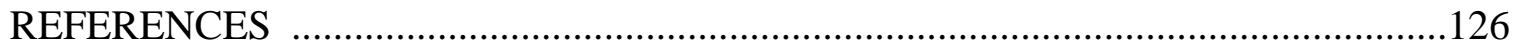

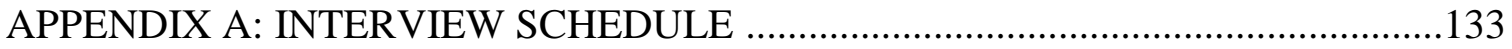

APPENDIX B: DEMOGRAPHIC QUESTIONNAIRE ..............................................136

APPENDIX C: CONSENT FORM ……………………..................................138 


\section{LIST OF TABLES}

Page

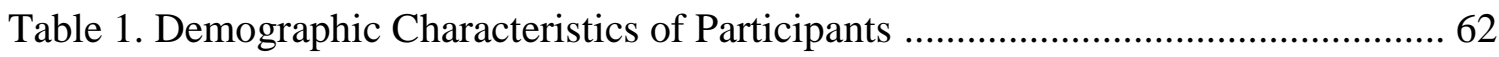




\section{LIST OF FIGURES}

Page

Figure 1. Consumer Decision-making Model ...................................................... 26

Figure 2. Clothing Consumption Process ........................................................... 41

Figure 3. Disposition Decision Taxonomy ….................................................. 42

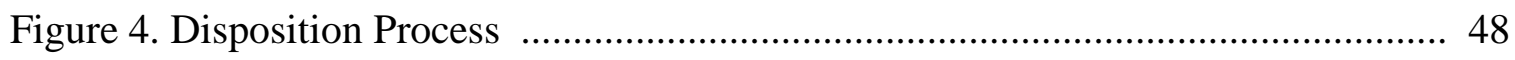

Figure 5. Hedonic and Utilitarian Categorization of Participants ................................119 


\section{CHAPTER I}

\section{INTRODUCTION}

\section{Statement of the Problem}

The economic downturn of the past two years has affected nearly every segment of the United States' economy. During the second half of 2008 and the first half of 2009, Gross Domestic Product (GDP) shrunk slightly and unemployment rose (AAFA, 2009). Americans have "tightened their belts" by reducing expenditures. Weaker consumer demand has hugely impacted the retailing sector in the United States. In particular, the apparel retail industry was hit by the recession. According to the American Apparel and Footwear Association (2009), apparel consumption for 2008 and 2009 actually fell by about $3 \%$. Consumers have become more price conscious and retailers have had to use more price competition to attract consumers and persuade them to make purchases.

Consumer confidence was greatly affected by the recession. Faced with fears of unemployment, foreclosure, and the destruction of the stock market, many consumers possessed little to no discretionary income while others were scared to spend their money. Slowly the economy has rebuilt itself, and consumer confidence is improving. Retailers and other businesses have again achieved profits. Yet the aftershocks of the 2008 recession may have been a wake-up call to consumers and changed their demands

from retailers (Gulati, Nohria, \& Wohlgezogen, 2010; Lasanti, 2010; Piercy, Cravens, \& Lane, 2010). 


\section{Second-hand Stores}

Faced with the current economic situation, it is plausible to predict that consumers

may have shifted their consumption patterns. One retail segment that may be of particular interest is that of second-hand stores. Second-hand stores sell slightly used merchandise at a fraction of the cost. The United States government classifies second-hand stores in a category called Used Goods Stores and has given it the NAICS code of 453310 (Shim, 2010). According to NARTS: The Association of Resale Professionals, the number of second-hand stores has risen by 7\% for 2008 and 2009 (n.d.). This comes at a time when many retail stores are experiencing store closings and negative profits.

Second-hand stores provide an interesting segment of the retailing economy that has been described as a "shadow economy" (James, Brown, Goodsell, \& Stovall, 2007). Characteristics of a shadow economy include being tax-exempt, less expensive, and more heavily focused on interpersonal interaction in addition to economic concerns (James et al., 2007). While major retailers report annual profit/loss statements and pay government taxes, much of the second-hand segment is tax-exempt. For this reason, some financial aspects of shadow economies are unknown. However, it is predicted that by 2015 profits in the second-hand segment will exceed $\$ 13.15$ billion annually (Shim, 2010). Within this segment, women's clothing is the largest sector comprising $19 \%$ of the used merchandise sold in 2010 (Shim, 2010). For this reason, focusing on women's used clothing consumption can be representational of the used merchandise market overall. 


\section{Types of Second-hand Clothing}

Second-hand clothing includes a broad assortment of types of clothing. For this research the definition of second-hand clothing does not include vintage or antique clothing. The majority of second-hand clothing purchased in the United States cannot be categorized as vintage or antique clothing. Vintage and antique clothing represent specialized segments of the clothing market in the United States, and these types of clothing are weeded out of the clothing market by collectors and dealers. Vintage clothing is typically at least 20 years old and representative of the era in which it was produced (Cicolini, 2005). However, standards do not exist to specify what and how clothing is categorized as vintage. Second-hand clothing from post-WWII decades that is deemed vintage can yield extremely high value and price-tags. Likewise, clothing that is over 100 years old is considered antique and can also wield a hefty price-tag. Due to its age and fragile condition, antique clothing is not meant to be worn but rather to be collected and displayed. Museums feature antique clothing as a way to appreciate the past. Antique clothing is an important aspect of the ethnography of cultures and time periods (Thomas, n.d.).

For the purpose of this research, second-hand clothing is defined as clothing that is excluded from vintage and antique clothing but that is in a condition that can be reused (Roux \& Guiot, 2008). Inquiry focusing on this more general type of pre-owned clothing, rather than those second-hand clothing items that fit into niche markets, such as vintage and antique clothing, allows broader generalizations about the second-hand clothing market to be made. 


\section{Consumption of Second-hand Clothing}

The purchase of second-hand clothing has existed throughout time. Before the industrial revolution, nearly all Americans wore used clothing because the supply of new clothing was severely limited. Apparel was mostly made in the home and the ability to purchase and wear new clothing that was not homemade was restricted to the wealthy and upper class (Tortora \& Eubank, 2009). With the technological advances in textile and apparel production as well as the outsourcing of labor, the prevalence of second-hand clothing became less common as more people were able to afford other forms of clothing (Fitzwater, 2005).

Traditionally, second-hand clothing consumption was assumed to be for those with the economic need for lower-priced goods (Winakor, 1969). However, recent research has implied that shopping at second-hand stores may be influenced by more than just economic reasons (Roux \& Guiot, 2008). Evidence of this is shown in that the practice of second-hand clothing consumption has not disappeared. Although a vast supply of new, inexpensive clothing exists in the market, some consumers prefer to purchase used clothing. The Used Goods Stores segment has experienced modest growth through the decades with predictors of growth an indirect result of unemployment, wages, and overall economic climate (Shim, 2010). While wearing second-hand clothing was once done out of necessity, a shift has occurred wherein some people wear second-hand clothing out of choice (Cicolini, 2005). Thus, while some consumers have an economic need to purchase second-hand clothing, this is not the case for all consumers of secondhand clothing. 
More recently, wearing second-hand clothing has become a more acceptable practice, even among those who can afford to purchase new clothing. The decision to purchase second-hand clothing has been identified as going "beyond the simple acquisition of a product discounted by the extent of its wear and tear and encompasses a particular form of shopping that competes with the use of conventional channels" (Roux \& Guiot, 2008, p. 64). Purchasing and wearing second-hand clothing is consistent with the zeitgeist of the times. The Encyclopedia of Clothing and Fashion (2005) describes the second-hand clothing trend as a "fashion zeitgeist" complete with cultural and economic influences. It notes,

From the 1970s onward, fashion commentators have often noted a marked plurality of styles, compared to the former singularity of fashion houses' diktats; a development engendering fertile environments for alternative, niche fashions, and retrogressive styling. Thus second-hand clothing has come to be seen as offering potential for expressing individual and more autonomous style (Hansen, 2005, p. 155).

Second-hand clothing fulfills a unique role which has not been fully identified but could yield interesting results.

While traditional retailers often focus on a particular target market to provide for, the target market for second-hand clothing is harder to identify. Some characteristics that second-hand clothing consumers are likely to possess have been noted. There has been a surge of younger consumers using second-hand clothing to accompany pieces in their closets. Mixing second-hand with new clothing has become trendy with college students making up a large portion of these consumers (Hansen, 2005). Proof of this is apparent with the prevalence of second-hand stores in close proximity to college campuses. One 
quality younger consumers look for in clothing is uniqueness (Reiley \& DeLong, 2011). The blend of styles and assortment of items available in second-hand stores make them appealing to this demographic.

In addition to being young, many consumers who purchase second-hand clothing can be described as environmentally friendly. An increasing number of consumers are concerned with the environment and have been attempting to live a green lifestyle. Second-hand clothing that finds new ownership is consequently kept out of the landfill. Additionally, many aspects of the textile and apparel production process have a detrimental environmental impact. From the pesticides used to grow cotton or the petroleum used in the production of synthetic fibers to dyeing the fabrics and packaging the final product, the amount of energy and resources used to manufacture new clothing has come to the attention of environmentally conscious consumers who seek alternatives to the typical new clothing purchasing process (Maycumber, 2008). The "going green" initiative has taken off in the past decades. Amidst an increased "throw away" society new efforts have been made to recycle or reuse clothing (Bianchi \& Birtwistle, 2010). The decreased environmental impact of second-hand clothing purchase has appealed to these consumers (Reiley \& DeLong, 2011). Environmentalists are focused on the importance for all consumers to do their part in saving the environment. But to encourage the behavior of others to use second-hand clothing, it is important to understand additional reasons why some people consume second-hand clothing while others do not. Understanding the motivations of second-hand clothing consumers is useful for retailers who wish to increase business (Wagner, 2007). 


\section{Hedonic and Utilitarian Shopping Motivations}

While previous studies (Bianchi \& Birtwistle, 2010; Reiley \& DeLong, 2011) have provided useful information about some of the demographic (e.g., young) and social psychological (e.g., eco-conscious) characteristics of second-hand clothing consumers, the specific drivers of second-hand purchase, especially shopping motivations, are largely unknown. In terms of shopping motivations, researchers have demonstrated a bias toward the purchase of new clothing when investigating hedonic and utilitarian motives (Allard, Babin, \& Chebat, 2009; Carpenter, 2008). When consumers are motivated to shop for hedonic reasons, they enjoy shopping for shopping's sake. They enjoy the social and emotional aspects associated with shopping behavior. Hedonic shoppers are concerned less with the acquisition of clothing products and more concerned with the overall experience they have while they are shopping (Babin, Darden, \& Griffin, 1994). On the other hand, when consumers shop for utilitarian reasons, they focus primarily on achieving the task and acquiring the clothing products they need to buy during the shopping trip. Utilitarian shoppers tend to behave rationally in shopping environments and are not concerned with social and emotional aspects associated with shopping (Babin et al., 1994).

Many researchers have investigated the hedonic and utilitarian shopping motivations of new clothing consumers. For example, Chang, Burns, and Francis (2004) found that female clothing consumers who were more hedonically motivated to shop also tended to be more satisfied with their clothing shopping experience than those consumers who were less hedonically motivated. Additionally, Wagner (2007) found that clothing 
consumers with different motivations for shopping desired different retail store attributes. In Scarpi's (2006) study, clothing consumers with primarily hedonic shopping motivation spent more money, purchased more items, and exhibited a higher degree of store loyalty in fashion stores than clothing consumers with primarily utilitarian shopping motives. Second-hand stores managers have taken notice of such demands from consumers, which is apparent in the increased emphasis being placed on the appearance of second-hand stores. Goodwill, one of the largest non-profit thrift retailers, has attempted to increase store patronage by revamping its merchandising displays (Cruz, 2010). Categorizing consumers as hedonic or utilitarian shoppers has proven useful for retail strategy creation and promotion design (Chang, Burns, \& Francis, 2004; McGoldrick, 2002; Scarpi, 2006; Wagner, 2007; Westbrook and Black, 1985). It stands to reason that investigating the shopping motivations of second-hand clothing consumers would be similarly fruitful for retailers.

Despite the fact that consumption of second-hand clothing has been steadily increasing, few researchers have investigated the shopping motives of second-hand clothing consumers. A few notable exceptions include Albinsson and Perera (2009) who interviewed participants of clothing exchanges, as well as Bardhi and Arnould (2005) who interviewed second-hand store patrons and Guiot and Roux (2010) who surveyed second-hand store patrons. The findings of these sets of researchers suggest that consumers purchase second-hand clothing for both utilitarian reasons, such as being economically priced, and hedonic reasons, including enjoying the excitement associated with hunting for treasures. Hence, similarly to new clothing purchase, second-hand 
clothing purchase may be motivated by aspects of both utilitarian and hedonic desires. Some consumers may be more hedonically motivated to patronize second-hand clothing stores. Other consumers may be motivated by more utilitarian reasons to shop at secondhand clothing stores.

It is not clear from the studies of Albinsson and Perera (2009), Bardhi and Arnould (2005), and Guiot and Roux (2010) if specific second-hand clothing consumers always experience hedonic or utilitarian motivation when shopping for second-hand clothing regardless of store type. It may be the case that, like new clothing consumers, second-hand clothing consumers' shopping motivations may vary when they are in different types of stores, such as for-profit consignment stores or non-profit thrift stores (Arnould \& Reynolds, 2003; McCabe, Rosenbaum, \& Yurchisin, 2007). It also remains unknown what demographic and social psychological factors may influence second-hand clothing consumers' shopping motivations. Extrapolating from previous research on new clothing purchasers (Seo \& Lee, 2008), it seems likely that motivations for purchasing second-hand clothing would also be affected by characteristics possessed by the consumer. Furthermore, it is not known in what ways, if any, the shopping motivations of second-hand clothing purchasers influence their behavior with respect to unwanted clothing from their wardrobes, including reselling or donating clothing. Due to the fact that many second-hand clothing retailers rely on individual consumers to provide inventory for them to sell, understanding the motivations of consumers in the disposal process is just as important as understanding their motivations in the purchasing process. 


\section{Clothing Disposition}

In addition to displaying a bias towards new clothing, researchers have also displayed a bias for investigating the clothing purchasing process as opposed to the clothing disposition process (Ha-Brookshire \& Hodges, 2008). The Engel, Kollat, and Blackwell (1968) model has been used extensively to examine clothing consumers' decision making process in the pre-purchase stages (Engel, Blackwell, \& Miniard, 1995; Lee \& Burns, 1993; Solomon, 2004; Van de Velde, Pelton, Caton, \& Byrne, 1996). Yet the clothing consumption process involves more than just purchase. According to Winakor (1969), the consumption process is comprised of acquisition, use, and disposal. As the final stage of the consumption process, understanding disposition could be as important as understanding the first two stages.

In Winakor's (1969) model, the disposition processes includes several options, such as selling and donating. Today, a multitude of channels exist in which consumers can rid themselves of unwanted clothing. Consumers can sell their clothing in bricks-andmortar consignment stores, like Plato's Closet, or on electronic websites, including e-Bay and Craigslist. Consumers can even use the internet to give their clothing away through sites like freecycle.com. By far the most popular manner in which to dispose of unwanted clothing, however, is by donating it to a charitable organization's thrift store (Birtwistle \& Moore, 2007; Hibbert, Horne, \& Tagg, 2005). Clothing donation centers such as Goodwill and Salvation Army are commonplace and rely on donated second-hand clothing to make money to support the community programs they fund. In this sense, the charitable organization's thrift store serves two functions. The thrift store can provide 
low cost clothing to people in need as well as use the money generated from the sales to fund other projects for those in need (Birtwistle \& Moore, 2007; Parsons, 2000).

The supply of second-hand merchandise is clearly influenced by the donation of clothing. Thus, these organizations have a vested interest in understanding why people donate clothing so that they can better manage inventory. Identifying factors that increase helping behavior, such as clothing donation, can lead to the development of more appropriate promotional strategies (Bendapundi, Singh, \& Bendapudi, 1996). One of the factors that may influence the amount of clothing donated to charitable organizations' thrift stores is motivation for donation, which, as some researchers have suggested (Birtwistle \& Moore, 2007; Ha-Brookshire \& Hodges, 2008), may include hedonic and utilitarian aspects. Organizations that rely on donations may increase their profitability by accurately promoting their cause through marketing strategies that appeal to consumers' motivations for donating (Ratchford, 1987). As a result, increased research in the area of clothing donation can yield positive economic gains.

\section{Hedonic and Utilitarian Donation Motivation}

Just as understanding the motivations for shopping have helped retailers plan their management and promotional strategies, understanding the motivations for donating clothing to charitable organizations could help the second-hand clothing retailers associated with these charitable organizations plan effective business strategies. Hanson (1980) has suggested that the apparel disposition decision-making process mirrors the apparel purchase decision-making process proposed by Engel et al. (1968). If Hanson's (1980) assumption is correct and the disposition process is similar to the acquisition 
process, it follows that aspects of the purchase process, such as shopping motivations, may also be present in the disposition process. That is to say, Babin et al.'s (1994) hedonic/utilitarian conceptualization would also apply to the disposition process.

The decision to part with unwanted or unneeded clothing is sometimes driven by economic necessity, particularly when individuals sell their clothing on websites or in consignment stores (Yurchisin \& Whitenack, 2007). Yet, the notion that disposition could be an emotional, as opposed to a rational, process is not without precedent. Lastovicka and Fernandez (2005) demonstrated that disposition is an emotional process. Individuals can use disposition to alleviate negative feelings or as a way to pass on positive feelings. Lastovicka and Fernandez (2005) state that participation in divestment rituals can ease the emotions individuals encounter when disposing of unwanted clothing. Since choice of clothing is often deeply personal and representational of an individual, what an individual chooses to wear, or consequently chooses to dispose of, is given a lot of thought. The decision to dispose of clothing can be attributed to a change in one's self-concept. Selfconcept is an organized configuration of perceptions of the self which are admissible to awareness, including perceptions of one's characteristics, values, and relationships (Solomon, 2004). Clothing that no longer is representational of an individual and does not fit with one's self-concept will not be of value anymore. However, positively or negatively charged meanings are still attached to the clothing. How and where unwanted clothing is disposed of can help an individual part with their possessions.

In terms of donation behavior, in particular, the work of Bendapudi et al. (1996) and Mitchell et al. (2009) also support the idea that individuals may be motivated to 
donate items to charitable organizations' thrift stores for emotional benefits. Although neither Bendapudi et al. (1996) nor Mitchell et al. (2009) were examining clothing donation behavior, per se, in both cases individuals' desire to donate to charity seemed to be driven by their desire to help other individuals in need, suggesting that donations of any type may involve hedonic, emotional motivations.

Researchers who have examined clothing donation behavior have noted motivations for donating that could be classified as hedonic and utilitarian. Birtwistle and Moore (2007) noted that donating unwanted clothing items to charitable organizations' thrift stores was associated with a positive emotional reaction among donors. Similarly, Ha-Brookshire and Hodges (2008) found that individuals mentioned that they donated clothing to charitable organizations' thrift stores in an effort to relieve feelings of guilt associated with owning too many clothing items. Participants in Ha-Brookshire and Hodges' (2008) study also mentioned that they donated unwanted clothing to make room in the closet. Thus, within one study, both hedonic, emotional reasons as well as utilitarian, rational reasons were cited by individuals as motivations for their clothing donation behavior. However, neither Birtwistle and Moore (2007) nor Ha-Brookshire and Hodges (2008) examined why individuals were motivated to donate clothing for hedonic or utilitarian reasons. If donation behavior is similar to purchase behavior in the sense that individuals can be motivated to engage in both behaviors for hedonic and utilitarian reasons, then it seems likely that demographic and social psychological factors would affect motivations for donation behavior as they do for purchase behavior (Seo \& Lee, 2008). 


\section{The Relationship between Purchasing and Donating Motivation}

Based on past research, it seems likely that the behavior of both second-hand clothing purchasers and second-hand clothing donors is driven by hedonic and utilitarian motivation. What remains unexplored is the relationship that may exist between the motivations, as well as the factors influencing individuals' motivations, for purchasing and donating second-hand clothing. While individuals may be primarily donors or primarily purchasers, the categories of donation and purchase are not mutually exclusive (Mitchell et al., 2009). Typically, however, the purchasing stages are studied separately from the disposition stages. One notable exception is Albinsson and Perera (2009) who examined women's behavior at a clothing exchange event. However, Albinsson and Perera (2009) focused on the disposition process and the modes of disposition. The motives that one individual has for both donating to and purchasing second-hand clothing from one retail context have not been examined. Additionally, the factors likely to affect those motives have also not yet been fully investigated in previous research.

Theoretically, examining donation and purchase motives offers a richer understanding of the complete process of clothing consumer behavior (Denegri-Knott \& Molesworth, 2009). Practically, identifying relationships that exist between consumers' motivations for donating to and purchasing from one charitable organization's thrift store can be valuable for store managers. Because it costs five times more to obtain a new customer than to retain an existing customer (Reichheld, 1996), managers of charitable organizations' thrift stores should view every donor as a potential purchaser and every purchaser as a potential donor. Managers of thrift stores could create more effective 
marketing strategies that could be standardized if the motives are similar or customized if the motives are different (Mitchell et al., 2009).

\section{Rummage Sale}

The Rummage Sale is an annual event that is sponsored by the Junior League of Winston-Salem in North Carolina. Frequently, charity organizations host events as a means of making money to promote their causes. In this particular organization, a large scale sale of donated items brings in nearly $\$ 90,000$ which is used to fund its programs for women and children in the community. In order for the event to be such a success, membership in the Junior League of Winston-Salem strongly encourages participation in the Rummage Sale. Participation can include donating items to be sold as well as volunteering during the event. The event is a member requirement but also boasts that "for many, some of their best moments, best friends, and best stories come from the hours worked at this event." As such, the Rummage Sale is a membership obligation but also a social event.

The Rummage Sale represents a context with both clothing disposal and acquisition processes occurring. Although the Rummage Sale is not a thrift store, per se, its operations are very similar to those of traditional, bricks-and-mortar non-profit thrift stores that are operated by other charitable organizations (e.g., Goodwill, Salvation Army). In thrift stores and at the Rummage Sale, the merchandise is donated by community members, volunteers sort the merchandise and prepare it for sale to the public, and all profits made are reinvested in community programs. The main difference 
between the Rummage Sale and other thrift stores is that the Rummage Sale is only in operation for one week as opposed to being open year round like thrift stores. Yet, despite this difference, the scale of the Rummage Sale is similar to that of thrift stores in that, in one week, the Rummage Sale brings in about the same amount of merchandise and sells about the same amount of merchandise that thrift stores sell annually.

Furthermore, unlike thrift stores, the Rummage Sale represents a single event where members of the Junior League of Winston-Salem are donating and purchasing second-hand clothing. In many other cases, consumers may not donate and purchase during the same shopping trip and may have trouble remembering their donation and purchase behavior if asked (Winakor, 1969). However, because donation and purchase occurs within a one-week time frame at one retail location, it should not be difficult for members of the Junior League to recall their purchase and donation behavior at the Rummage Sale.

Additionally, although the members of the Junior League are not representative of the entire population of consumers, they do represent an important segment of the donating and purchasing public. As women, the members of the Junior League are responsible for the majority of the clothing consumption decisions for themselves and the other members of their households (Gogoi, 2005). Hence, identification of the donation and purchase motivations of the members of the Junior League at the Rummage Sale can potentially provide useful insight to second-hand clothing retails in other contexts. Thus, the Rummage Sale is an appropriate context in which to study donation and purchase behavior. 
The current study is guided by the following research questions: 1) What motivates the second-hand clothing purchase behavior of the members of the Junior League at the Rummage Sale? 2) What motivates the clothing donation behavior of members of the Junior League during the Rummage Sale? 3) What factors affect the motivations for purchasing and donating experienced by the members of the Junior League at the Rummage Sale? 4) In what ways, if any, are the motivations mentioned by the members of the Junior League for their second-hand purchasing behavior related to the motivations for their donation behavior at the Rummage Sale?

\section{Research Purpose and Objectives}

The purpose of this research was to investigate the motives of second-hand clothing consumers who both purchase from and donate to the retail outlet associated with one charitable organization. More specifically, individuals' motivations for donating clothing were compared to their motivations for purchasing second-hand clothing from the same location using the hedonic/utilitarian framework. Furthermore, the demographic and social psychological factors affecting individuals' motivations for donating to and purchasing second-hand clothing from a charitable organization's retail outlet were examined. Little research has been conducted in the area of clothing donation and second-hand clothing purchase, and no research could be located in which both processes were examined in the same study. The present study aimed to see if there is a connection among the two processes. The objectives of this study included: 
1) To explore second-hand clothing consumers' motivations (e.g., hedonic, utilitarian) for purchasing clothing from the retail outlet associated with one particular charitable organization (i.e., Junior League Rummage Sale).

2) To examine the demographic (e.g., age, income, marital status) and social psychological factors (e.g., eco-consciousness, need for uniqueness, price consciousness) that may have an impact on consumers' motivations for purchasing second-hand clothing from the retail outlet associated with one particular charitable organization (i.e., Junior League Rummage Sale).

3) To uncover second-hand clothing consumers' motivations (e.g., hedonic, utilitarian) for donating clothing to the retail outlet associated with one particular charitable organization (i.e., Junior League Rummage Sale).

4) To investigate the demographic (e.g., age, income, marital status) and social psychological factors (e.g., eco-consciousness, need for uniqueness, price consciousness) that may have an impact on consumers' motivations for donating clothing to the retail outlet associated with one particular charitable organization (i.e., Junior League Rummage Sale).

5) To identify the relationships that exist, if any, between second-hand clothing consumers' motivations (e.g., hedonic, utilitarian) for purchasing from and donating to the retail outlet associated with one particular charitable organization (i.e., Junior League Rummage Sale).

6) To explore the relationships that exist, if any, between the factors (i.e., demographic and social psychological) that influence second-hand 
consumers' motivations (e.g., hedonic, utilitarian) for purchasing from and donating to the retail outlet associated with one particular charitable organization (i.e., Junior League Rummage Sale).

\section{Significance of the Study}

This goal of this research was to investigate second-hand clothing consumers' donation and purchase behavior within one retail context. Previous research has examined these processes individually but research has not been conducted to see if there is any connection between the second-hand clothing purchase and donation behavior of consumers in one study. More specifically, the motivations as well as the factors influencing the motivations associated with second-hand clothing purchase for one individual were compared to those associated with clothing donation for the same individual. From a theoretical standpoint, the study will fill a gap in the knowledge. While hedonic and utilitarian motivation has been examined with respect to second-hand clothing purchase and donation behavior, consumers' motives for both donating and purchasing second-hand clothing have not yet been investigated within the same study. By considering both processes within one retail context, a more complete understanding of the whole consumption process, from problem recognition through disposal, is obtained. Furthermore, the present study is useful to practitioners, especially managers of thrift stores associated with charitable organizations. Because these stores rely upon both donations and purchases for success, a more complete understanding of the motivations

of donors and purchasers and any differences that impact the motivations that donors and 
purchasers have can assist managers with efforts to increase revenue and fund community projects.

\section{Organization of the Study}

This research paper begins with an introduction about the second-hand clothing market and what influences it. The purpose and significance of this research project are also mentioned in the introduction. This is followed by a detailed literature review of previous research in the area of second-hand clothing as well as similar areas. Research projects are mentioned that have particular significance to this topic. The third section is the methodology section which details the data collection process. The final two chapters will discuss the interpretation of the data as well as the discussions and implications. Lastly, research limitations and future research directions are suggested.

\section{Definition of Key Terms}

Acquire

Clothing exchange

Contamination
The first stage of the disposition process (Winakor, 1969); to come into possession or ownership of (dictionary.com).

Event which entails swapping clothing while socializing. Key feature is that there is no monetary exchange (Albinsson \& Perera, 2009).

The transfer of real (e.g., stains, disease) or imagined (e.g., memories, emotions) characteristics associated 
with a product from the original owner to a new owner. Contamination can be positive (memories from a loved one) or negative (inconsistent with selfconcept). (Roux \& Korchia, 2006).

Donation behavior

Disposal

Evaluation of Alternatives

Hedonic value 
Motivation

Non-profit thrift store

Problem recognition

Post-purchase evaluation
An internal state that activates goal-oriented behavior (Solomon, 2004). Motivation can be rational (utilitarian) or emotional (hedonic) (Engel, Blackwell, \& Miniard, 1995).

Accept clothing donations that are tax-deductible; profits are reinvested in community programs (Shim, 2010).

a) The first step in the consumer decision making process (Engel, Kollat, \& Blackwell, 1968). Occurs when a discrepancy in an individual's ideal and actual state exists and a need for a product is experienced (Solomon, 2004).

b) The first step in the consumer disposition decision-making process (Hanson, 1980). Occurs when a discrepancy in an individual's ideal and actual state exists and a need to dispose of a product is experienced.

The fifth and final step in the consumer decision making process (Engel, Kollat, \& Blackwell, 1968). Characterized by level of satisfaction with the product (Solomon, 2004). 
Purchase

Second-hand clothing

Second-hand store

Self-concept

Utilitarian value

Use
The fourth step in the consumer decision making process; occurs when the consumer acquires the preferred alternative or an acceptable substitute (Engel, Blackwell, \& Miniard, 1995).

Clothing capable of being reused, in good condition or repairable (Roux \& Guiot, 2008).

Sells slightly used merchandise at a fraction of the cost (Shim, 2010).

An organized configuration of perceptions of the self which are admissible to awareness, including perceptions of one's characteristics, values, and relationships (Engel, Blackwell, \& Miniard, 1995). Benefits resulting from purchase or other consumer decisions that are objective, functional product attributes (Engel, Blackwell, \& Miniard, 1995). Second stage of the disposition process, involves employing the object in the way it was intended (Winakor, 1969). 


\section{Summary}

This chapter discussed the purpose of the study which included pertinent background information. The significance, objectives, and key terms were detailed.

Justification for the use of the Rummage Sale as an appropriate context to investigate the motivations of individuals who both donate to and purchase second-hand clothing from one charitable organization's retail outlet was presented. The next chapter will include a review of extant literature about the topics of interest. 


\section{CHAPTER II}

\section{LITERATURE REVIEW}

This chapter provides an overview of the literature related to the clothing consumption process. Specifically, the literature pertaining to the purchase of new and second-hand clothing is reviewed. Similarly, the research related to the disposition of clothing is presented, with an emphasis being placed on donation behavior. The concepts of utilitarian and hedonic motivation for purchase and donation are discussed.

The Engel, Kollat, and Blackwell Consumer Decision-Making Model

The consumption process has been studied extensively, and the Engel et al. (1968) model has been used repeatedly to understand consumer decision-making (Engel et al., 1995; Lee \& Burns, 1993; Solomon, 2004; Van de Velde et al., 1996). According to Engel et al. (1968), consumer decision-making can be described through a five point process. The consumer decision-making model is made up of (1) problem recognition, (2) information search, (3) evaluation of alternatives, (4) purchase, and (5) post-purchase evaluation. A consumer will progress through each of these steps in order to satisfy his or her needs. Problem recognition occurs when an individual experiences a difference between his or her actual state and ideal state (Solomon, 2004). In the instance of clothing consumption, this can occur when an individual recognizes the need for something to wear. Once the problem is identified, the second step includes searching for the appropriate product. People often look to others for assistance when searching for 
information. Searching for information about the clothing decision can be accomplished through personal channels, like asking friends and family, or outside channels, such as the news, media, or Internet (Mitchell et al., 2009). Marketers know this and try to present information in ways that will encourage individuals to want the products they represent. As information is acquired it is processed and evaluated by the individual, which is the third step of the model. Evaluation can occur based on many aspects and once the individual feels that a sufficient product has been found, purchase occurs. Through these steps, the consumer makes a decision and acquires the desired product. The final stage of the consumer decision-making process includes post-purchase evaluation. Post-purchase evaluation can be positive or negative and can include aspects related to the product, itself, as well as experiences associated with the product. Examples of post-purchase evaluation related to the product include the perceived quality, whereas enjoyment of purchase and use correspond to the experiences associated with the product (Solomon, 2004). Figure 1 presents these five steps graphically.

Figure 1. Consumer Decision-making Model.
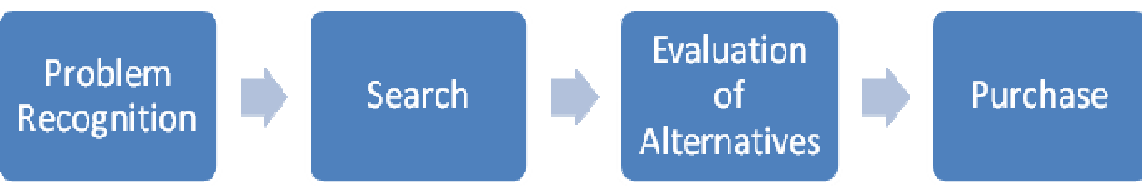

Post Purchase Evaluation

Source: Engel, Kollat, and Blackwell (1968) 
The Engel et al. (1968) model provides a useful framework for understanding the general process of consumer decision-making. However, the model does have several limitations. Although the model suggests that consumers always behave in a logical, rational fashion, previous research suggests otherwise (Pachauri, 2002). While typically each of these steps is completed when a decision is made, sometimes the consumer may not be explicitly aware of each of the steps. For example, in the instance of unplanned or impulse buying, a consumer may not spend a detailed amount of time evaluating alternatives but rather hastily make a purchase decision (Solomon, 2004; Tauber, 1972). Furthermore, the time and attention paid to each step can be varied based upon the individual, the item and the situation. For instance, individuals who are highly involved with a product category will proceed through the steps in a different way than those who are less involved with the product category. The level of involvement that a consumer experiences can affect the extent and attention paid to each of the steps of the decisionmaking process. The process for low-involvement, frequently purchased items such as food will differ from the process for high-involvement, infrequently purchased items such as cars. The shopping environment can also have an impact on consumers' behavior, causing them to spend more or less time advancing through the steps (Solomon, 2004; Winakor, 1969).

Additionally, the Engel et al. (1968) model indirectly suggests that acquiring a product is the only goal of every person's shopping trip. While purchase of an item is perhaps one goal, some people shop for other reasons besides product acquisition. In their groundbreaking studies, Stone (1954) and Tauber (1972) found that people have many 
reasons for shopping, some of which are not product-related. Tauber (1972) identified three distinct activities of consumers; shopping, buying and consuming. While buying refers to the actual acquisition of a product and consuming refers to the use of the product, shopping can be more complex and involve various motivations. Within the category of shopping, Tauber (1972) identified motives that can be personal or social. Personal motives include role playing, diversion, and self-gratification whereas social motives include being with others or even feeling authority over sales personnel (Tauber, 1972). The activity of shopping itself can be the motive of a shopping trip and the acquisition of products may be an afterthought rather than the overriding purpose of the trip. Likewise, Stone (1954) identified four types of consumers based upon their social characteristics. These consumer types organize shoppers as economic, personalizing, ethical, or apathetic. Economic shoppers are overwhelmingly focused on the acquisition of a product, weighing the pros and cons of purchase in terms of financial reasons, while personalizing shoppers may focus more on other aspects of the shopping experience, such as customer service. Ethical shoppers base their consumption decisions on moral obligations whereas apathetic shoppers do not put much thought into the stores they patronize (Stone, 1954). Thus, a thorough understanding of the consumption process requires an examination of the different motivations that people have for shopping (Westbrook \& Black, 1985). 


\section{Motivations for Shopping}

\section{Cognitive Social Psychological Perspective-Field Theory}

The theoretical basis for understanding consumer motivations is rooted in a cognitive social psychological perspective (Ross \& Iso-Ahola, 1991). According to the behaviorist paradigm, people's behavior is a simple reflexive response to stimuli (Farr, 1996; Sandstrom, Martin, \& Fine, 2003). In other words, behaviorists believe that all human behavior is merely an automatic response to some type of environmental stimuli. For example, if an individual touches a hot surface, he or she will recoil his or her hand immediately to avoid pain and harm, without making a conscious decision to do so. On the other hand, cognitive social psychologists, like Kurt Lewin, argue that when individuals encounter a stimulus, they must analyze and interpret the stimulus prior to reacting to it (Farr, 1996). That is to say, individuals' behavior is a response to their perceptions of specific situations (Engel et al., 1968), and their perceptions of specific situations are guided by the ways in which they organize and process mental information (Sandstrom et al., 2003). Hence, rather than responding in an automatic fashion, individuals consider the factors related to the situation, evaluate their options, and then decide how to behave.

According to Lewin's (1951) field theory, individuals' cognitions and perceptions of stimuli are shaped by all of their past experiences. This accumulation of information is referred to by Lewin (1951) as an individual's psychological field. Because people have unique life experiences, their psychological fields will differ. However, given that individuals live within cultures that operate with social rules and conventions, the 
behavioral responses displayed by individuals who have different psychological fields tend to differ in predictable ways when they encounter similar stimuli.

In the case of consumption behavior, Engel et al. (1968) proposed that the consumer decision-making process begins with problem recognition. The problem experienced by consumers is a discrepancy between their current state and their ideal state. Lewin (1951) explained that such discrepancies created a state of tension within the individual, and this tension would motivate the person to reach his or her ideal state. In other words, consumers who are aware of this discrepancy recognize that they have a particular goal that they are motivated to achieve. The process of motivation involves "the drives, urges, wishes, or desires which initiate the sequence of events known as 'behavior'” (Bayton, 1958, p. 282). For some consumers, the behavior of shopping may be motivated strictly by the desire to obtain a new product. For these so-called "utilitarian" consumers, the behavior of shopping is solely a means for achieving the goal of purchasing a product (Babin et al., 1994). For other consumers, the behavior of shopping may be motivated by the goal of achieving a different desired ideal state. For these "hedonic" consumers, shopping may represent a fun, exciting, social behavior that helps them relieve boredom and interact with others while also potentially acquiring a product in the process (Babin et al., 1994).

\section{Hedonic Versus Utilitarian Shopping Motivation}

The research of Babin et al. (1994) describes the utilitarian/hedonic dichotomy as it applies to shopping. Simply put, utilitarian values are concerned with the need for something while hedonic values are concerned with the desire or want. In the context of 
shopping, utilitarian values include focusing on the price or speed of acquiring a product to produce feelings of a successful trip. Information is gathered in a rational and logical manner and shopping is deliberate and efficient (Babin et al., 1994). Conversely, with hedonic value, a shopping trip can still be successful if no product is acquired but rather the overall experience of the shopping trip is what makes it successful. Greater emphasis is placed on fun and pleasure and hedonic value can be much more subjective than utilitarian value (Babin et al., 1994).

While utilitarian and hedonic values are opposing they are not exclusive of each other. It is possible for both utilitarian and hedonic aspects to be present during a shopping trip. The example used by Babin et al. (1994) of a shopping trip that combines utilitarian and hedonic aspects is when "a consumer might find the product that motivated the shopping trip at an exceptionally low price at the first store visited" (p. 647). The presence of both utilitarian and hedonic features is pleasing to the consumer. At the same time, however, it is possible that the availability of one may inhibit the availability of the other. Often, items on sale with a lower price that would be considered as having utilitarian value may have a limited selection so that the desired style is not available. In this instance utilitarian aspects limit the availability of hedonic aspects. Likewise, a person may go shopping to improve their mood but end up spending a lot of money which would satisfy the hedonic but not utilitarian value of shopping.

It is also possible for one consumer to be motivated to shop at different retail locations for different reasons (Arnould \& Reynolds, 2003; McCabe, Rosenbaum, \& Yurchisin, 2007). For instance, a consumer may be motivated to shop at a grocery store 
in a utilitarian fashion, following a shopping list in a rational manner, but be motivated to shop at a high-end department store to fulfill emotional needs, like social status.

Additionally, it is possible for different consumers to be motivated to shop at the same retail location for different reasons. Some consumers may enjoy shopping at off-price retailers, like T. J. Maxx, to save money because they are motivated to behave in a utilitarian manner, while other consumers may enjoy shopping at the same store because they are motivated by the hedonic aspects associated with the excitement of searching for and locating a special item. And, it is possible for one consumer to be motivated to shop at one retail location for both utilitarian and hedonic reasons (Diep \& Sweeney, 2008).

Researchers have investigated the hedonic/utilitarian dichotomy and discovered information in relation to gender differences (Chang et al., 2004; Diep \& Sweeney, 2008) and social class (Seo \& Lee, 2008). Diep and Sweeney (2008) found that the overall shopping trip value felt by a consumer is based upon the hedonic or utilitarian value of the store, the product, and the shopping trip itself. They also found that gender differences exist in shopping motivation wherein women are more likely to experience higher hedonic shopping trip motivation (Diep \& Sweeney, 2008). Seo and Lee (2008) found that compared to the lower-middle class, upper-middle and upper classes scored higher on experiential shopping which was characterized by the interest in the shopping experience itself. However, these results were not found when looking at shopping at discount stores. So it appears that the type of store has a moderating effect on social class differences in store value. The hedonic and utilitarian motivations for shopping have been primarily focused on consumer behavior in stores selling new products (Allard, Babin, \& 
Chebat, 2009; Carpenter, 2008). It is not known if the results found in other retail stores would be the same in second-hand clothing stores. Because of this research bias toward investigating the motivations of consumers in the new clothing market, the motivations of consumers representing a large segment of the overall clothing market, the second-hand clothing market, remain unexplored.

One notable exception is Bardhi and Arnould (2005) who proposed that purchasing second-hand items is both a utilitarian and hedonic practice. Their work concluded that second-hand consumption fulfilled aspects of what the authors refer to as "thriftiness" and "fun" (Bardhi \& Arnould, 2005, p. 226). In other words, consumers are motivated to shop in second-hand stores by their desire to save money as well as their desire to enjoy themselves. Thriftiness pertains to the aspects which are considered utilitarian while fun falls under the hedonic categorization. Although Bardhi and Arnould (2005) did not specifically investigate second-hand clothing shopping, it was a product category frequently discussed by participants. As a result, many of the findings seem applicable to the purchase of second-hand clothing.

Interesting findings from Bardhi and Arnould's (2005) study included the notion that people often purchase second-hand clothing and then dispose of it without ever using it. The price for second-hand clothing is often a fraction of that of new clothing which can attribute to the utilitarian value. Yet a low price can increase the likelihood that the product is purchased even if it is not needed. If an item is located during a "treasure hunt," that item may be purchased because locating a treasure during the hunt represents an emotionally, hedonically satisfying experience. These responses indicated that 
shopping for second-hand clothing was not always a planned event. Unplanned purchases are common and shopping trips were described as being motivated by "the thrill of the hunt" (Bardhi \& Arnould, 2005). Tauber (1972) also indicated that shopping can be impulsive rather than being initiated after a specific need for a product is recognized. Thus, it seems that, like new clothing, consumers may be experiencing utilitarian motivation or hedonic motivation to shop for and purchase second-hand clothing. However, more research needs to be conducted specifically on motivations for shopping for second-hand clothing in other contexts to lend support to this contention.

In addition to Bardhi and Arnould (2005), Guiot and Roux (2010) also investigated the motivations of second-hand store consumers. Although not a study of second-hand clothing consumption, Guiot and Roux (2010) also found that consumers in second-hand stores were motivated to purchase for either hedonic or utilitarian reasons. Guiot and Roux (2010) extended their investigation to also examine the factors that influenced consumers' motivations for shipping in second-hand stores. These researchers found that utilitarian consumers tended to be younger and more frugal than hedonic consumers in second-hand stores. Hedonic consumers tended to be older and have a higher need for uniqueness than utilitarian consumers in second-hand stores. In Guiot and Roux's (2010) study, environmentally concerned consumers tended to be more hedonic and less utilitarian in terms of their motivations for purchasing from second-hand stores.

While Guiot and Roux's (2010) study supplies support for the notion that the utilitarian/hedonic conceptualization can be useful for categorizing second-hand store consumers, these researchers did not examine second-hand clothing consumption. Hence, 
it is not known if the findings of Guiot and Roux (2010) apply to consumers of secondhand clothing. A study conducted by Yavas and Riecken (1981), however, does lend support for the utilitarian/hedonic conceptualization of second-hand clothing purchasers, in particular. Yavas and Riecken (1981) compared the motivations of light, medium, and heavy shoppers in a second-hand store. All consumers, regardless of how often they shopped in the second-hand store, were motivated to shop in the second-hand store because the prices were low, suggesting that consumers may be motivated to shop in second-hand stores for utilitarian reasons. However, those consumers categorized as light and medium shoppers placed more importance on the adventure/treasure hunting aspects of their shopping experience than did those consumers categorized as heavy shoppers. This suggests that consumers who shop less often tend to shop more for hedonic reasons than consumers who shop more often. Although Yavas and Riecken (1981) did not investigate the social psychological factors that affected how often consumers shopped at the second-hand store, their findings do demonstrate that different consumers may have different motivations for shopping at second-hand stores. Furthermore, even though Yavas and Riecken (1981) did not specifically investigate the purchase of second-hand clothing, adult and children's clothing was mentioned as a product category frequently purchased by shoppers. Therefore, it seems likely that their findings could be applied to the second-hand clothing market. But further research needs to be conducted on the motivations of different second-hand clothing consumers before definitive conclusions can be drawn. 


\section{The Second-hand Clothing Market}

The scope of second-hand stores includes "thousands of single location shops, hundreds of multi-location chains, franchises, and Not for Profit thrift stores" (NARTS, n.d.). According to NARTS, 16-18\% of Americans shop at second-hand stores every year for some type of product (n. d.). Due to the many undocumented transactions of second-hand items, exact data for this shadow economy is unknown and could be even higher. It can be stated that the market for second-hand items is enormous and clothing constitutes a large part of this market. The impact of second-hand clothing markets are currently only vaguely understood but further research could uncover interesting themes and possible shifts over time.

\section{Types of Second-hand Clothing Stores}

Second-hand clothing can be purchased in a variety of channels. Some of these are based on clothing resale (e.g., consignment, auction, online, eBay). Others rely on donations (e.g., clothing exchange and non-profit store). Non-profit stores that accept clothing donations are classified and regulated by the government and donations to these organizations are tax-deductable. Non-profit thrift stores are the most prevalent type of second-hand clothing stores so they provide the greatest availability for those looking to purchase second-hand clothing (Shim, 2010).

\section{Hedonic and Utilitarian Motivation for Purchasing Second-hand Clothing}

Past research states that second-hand clothing purchase is propelled by an economic need for lower-priced items (James et al., 2007; Winakor, 1969). Economic 
reasons are consistent with the notion of clothing at its most basic, utilitarian level—as protection from the elements. However, clothing also serves additional purposes.

Clothing is a special product. Clothing is a means of self-expression with deeply personal symbolic meanings. Clothing has many different functions that include status symbols and expressions of identity. Clothing choice becomes a product of an individual's personalized consumption meanings (Roux \& Korchia, 2006; Thompson \& Haytko, 1997). The purchase of clothing presents a unique process that has been identified as "a process that combines a greater variety of complicating factors than do those for most other goods" (Winakor, 1969, p. 632). As a result, the notion of shopping for and wearing used clothing allows consumers to express aspects of their personalities besides their economic, or utilitarian, need. Roux and Guiot (2008) state that "motivation toward second-hand shopping refers to the psychological and material motives that in general orient people toward second-hand products and/or distribution channels" (p. 68). Thus, it seems that shopping for and purchasing second-hand clothing might be motivated by hedonic reasons.

Because of clothing's varied functions, many of which are related to the emotional and psychological state, clothing is often referred to as a "hedonic" product (Solomon, 2004). This does not imply, however, that consumers' only motivation for purchasing apparel is hedonic. As previous researchers have found, new clothing consumers (Seo \& Lee, 2008) and potentially second-hand clothing consumers (Bardhi \& Arnould, 2005; Yavas \& Riecken, 1981) can be motivated to purchase apparel for both utilitarian and hedonic reasons. 
While research is limited, some work has been conducted to identify demographic and social psychological characteristics that wearers of second-hand clothing are likely to possess. For instance, wearing recycled clothing may express the social psychological characteristic of social responsibility (Dickson, 2000). A socially responsible consumer is defined as "one who purchases products and services which he or she perceives to have a positive (or less negative) impact on the environment or uses his/her purchasing power to express social concerns" (Roberts, 1995, p. 98). The idea of social responsibility as a motivation for second-hand clothing purchase has not been researched specifically but research about the motivations for second-hand donation has shown that social responsibility and concern for the environment rank high on the list for donation motivation.

Age, a demographic characteristic, has been identified as a characteristic of second-hand clothing purchasers with younger consumers being more prone to shop for second-hand clothing (Mitchell et al., 2009). Similarly, Reiley and DeLong (2011) found that vintage clothing purchasers were likely to be young and desire uniqueness. In their study, college-aged females were interviewed about their consumption habits of both vintage and new clothing. The researchers discovered that a desire for uniqueness, a social psychological characteristic, was more prevalent when purchasing vintage clothing (Reiley \& DeLong, 2011). Although Reiley and DeLong's (2011) study specifically pertains to vintage clothing, it seems likely that second-hand clothing, in general, would also fulfill one's need for uniqueness. Second-hand clothing is unique which appeals to consumers who wish to seek counter-conformist consumption (Roux \& Korchia, 2006). 
The notion of not looking like everyone else and being individualistic has been noted as appealing to second-hand clothing consumers (Roux \& Korchia, 2006).

Although some characteristics of second-hand clothing consumers have been identified, it is not yet known how these characteristics may impact second-hand clothing consumers' motivations for purchase. It is also not known what other social psychological factors may be likely to affect second-hand clothing consumers' motivations. Not understanding the motivations for second-hand clothing purchase may be hindering the performance of non-profit thrift stores (Chang et al., 2004; McGoldrick, 2002; Scarpi, 2006; Wagner, 2007; Westbrook \& Black, 1985), the most popular type of second-hand clothing retailer (Shim, 2010).

In recent times, sales of clothing in charitable organizations' non-profit thrift stores have increased (NARTS, n.d.). Growth in this segment continued throughout the 2008 recession which was characterized by significant losses by traditional retailers. Increases in sales in charitable organizations' thrift stores represent a unique challenge for store managers. Because these thrift stores rely on donations of clothing to replenish their inventory, donations need to increase as sales increase. As a result, managers need to understand the motivations for both purchasers and donors in order to effectively run their stores. But the motivations for donation behavior, along with all clothing disposition behavior, have not been researched enough. 


\section{The Clothing Disposition Process}

The various reasons and needs for clothing lead to a significant amount of clothing acquisition throughout a person's life. Acquiring clothing results in the necessity to dispose of clothing later. Despite the inevitability of disposition, the clothing disposition process has not been investigated fully (Ha-Brookshire \& Hodges, 2008).

Clothing disposition does appear in Winakor's (1969) clothing consumption process model. The clothing consumption process is made up of acquisition, inventory, and discard (Winakor, 1969). Clothing is added through the process of acquisition and removed through the process of disposal. The continuous flow and acquisition and discard makes up the inventory of clothing which is described by Winakor (1969) as a "bathtub model” (p. 630). Figure 2 presents the three steps in Winakor's (1969) process.

There are various reasons to dispose of clothing and Winakor (1969) notes that the physical state of clothing is not the only determinant. The majority of disposed clothing is due to poor fit or fashion (Winakor, 1969). Additional influences for the disposal of clothing can be contingent on the wearer such as the age and activity of the wearer, the amount of other clothing, and access to clothing care and maintenance (Winakor, 1969). The presence of the fashion complex has expedited the process by which clothing goes out of fashion (Jin, Chang, Matthews, \& Gupta, in press) which may be an explanation for increased disposal. The recent introduction of fast fashion, which is characterized by increased speed and availability of new fashions at low cost, has further increased the rate of clothing acquisition (Jin et al., in press). Due to the relatively new attention paid to clothing disposal, variations or patterns of disposal are not known. 
Winakor (1969) notes that clothing disposal may be more difficult to capture than clothing acquisition because recall of product disposition can be more difficult to recall than purchase. In addition, product acquisition is easy to pin point whereas sometimes the exact moment of disposal may not be. Some clothing is not worn or becomes inactive but not necessarily disposed of. Likewise, the inventory process can include care and active storage of clothing which may result in clothing being unavailable to use but not necessarily permanently gone (Winakor, 1969).

Figure 2: Clothing Consumption Process.

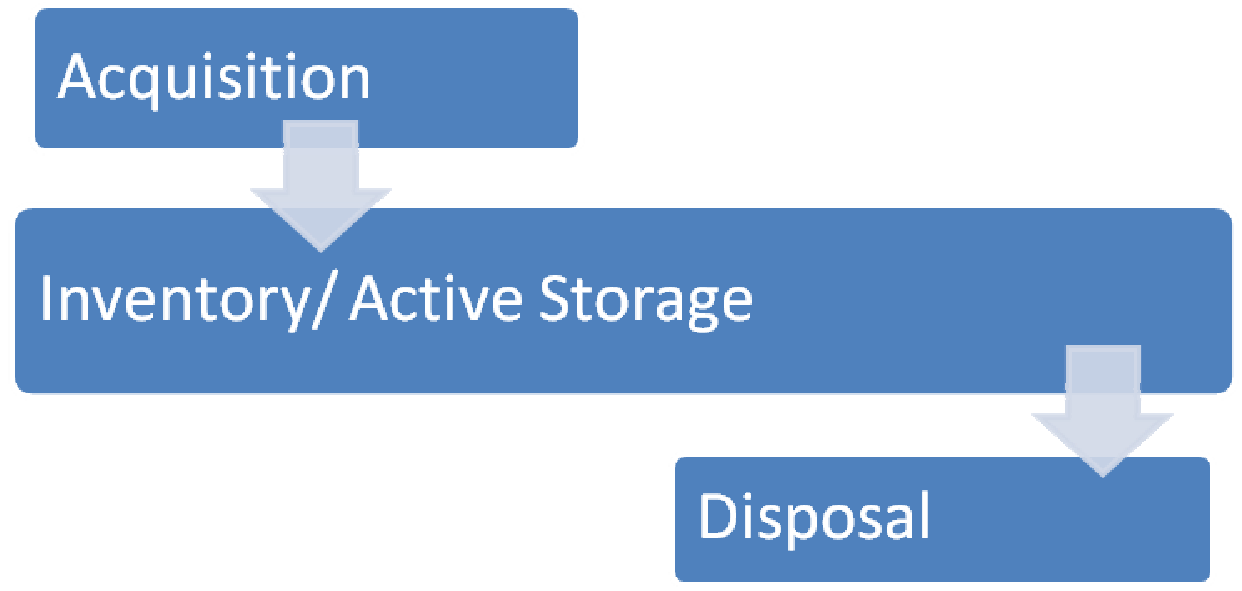

Source: Winakor (1969)

Methods of Clothing Disposition

Once the decision has been made to dispose of a clothing item, consumers have several more decisions to make. Jacoby, Berning, and Dietvorst (1977) surmise that when disposing of a product the options are to (1) keep the product, (2) permanently dispose of it, or (3) temporarily dispose of it. Manipulating a product or finding an alternative use 
for the product is a way to keep the product. However, if no other use for the clothing is found, either permanent or temporary disposition occurs. The difference between temporarily and permanently disposing of an object refers to whether or not the person wants to get the product back. Lending an item to another person or storing the item away are ways in which it can be temporarily disposed of.

Although Jacoby et al.'s (1977) model is not specific to clothing, researchers who have investigated clothing disposition (Bianchi \& Birtwistle, 2010; Winakor, 1969) mention the same methods that Jacoby et al. (1977) presented for permanently disposing of clothing. Figure 3 presents Jacoby et al.’s (1977) process.

Figure 3: Disposition Decision Taxonomy.

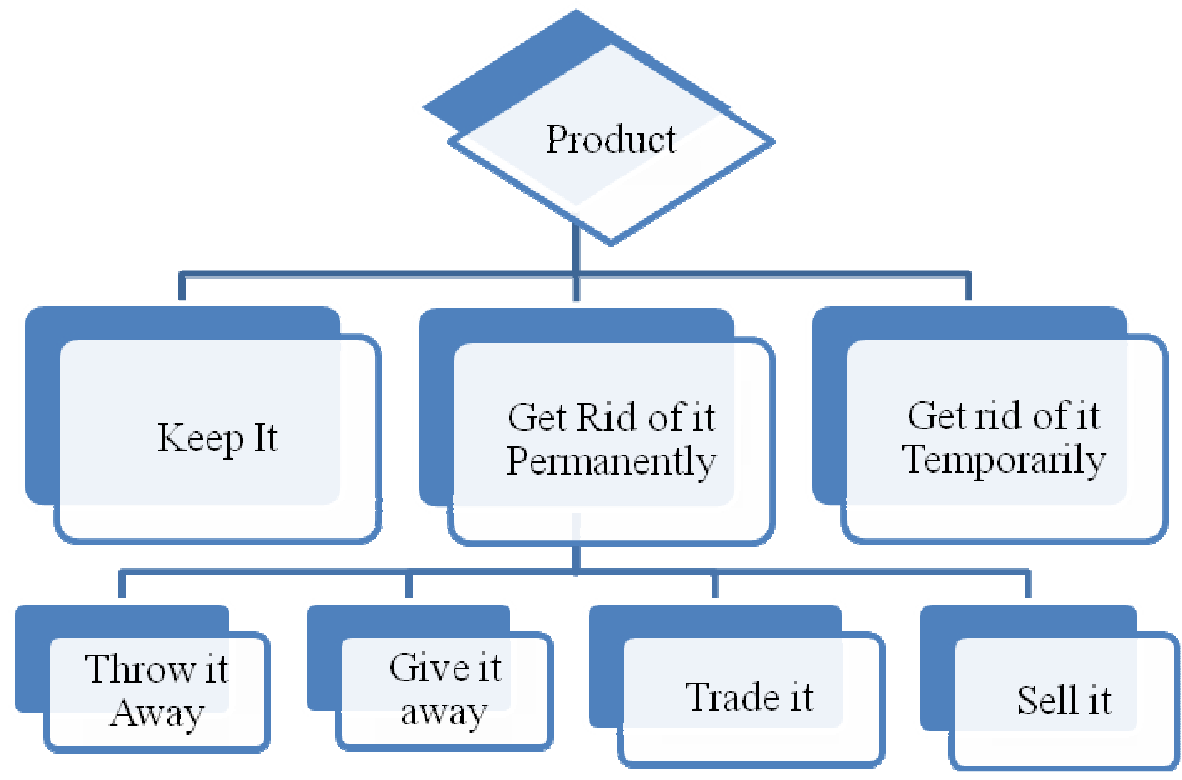

Source: Jacoby, Berning, and Dietvorst (1977)

Within the decision to permanently get rid of clothing, the options then become (1) throw it away, (2) give it away, (3) trade it, or (4) sell it. Each of these options is a 
viable choice which will have implications for the individual and also for society. For example, when clothing is thrown away it will be taken to the landfill. This method of disposal is inconsistent with the environmentally friendly attitudes of many of today's clothing consumers (Bianchi \& Birtwistle, 2010). Rather than simply throwing unwanted clothing away, many individuals attempt to breathe new life into their old clothing by passing the clothing item to a new owner.

When individuals decide to pass their unwanted or unneeded clothing on to a new owner, they have several options to choose from. Within the Jacoby et al. (1977) disposal decision categorization of trading clothing, clothing exchanges are one method. During clothing exchanges, participants swap items so clothing is given away without monetary compensation but rather an exchange for other clothing (Albinsson \& Perera, 2009). Clothing exchanges are social events that are gaining popularity as a way to dispose of clothing. While clothing exchanges are typically held in an offline location, online versions of the same concept exist. For example, Freecycle is a website that acts as a digital bulletin board to connect people and facilitate the transfer of unwanted things to those who may want them.

There are also numerous outlets to dispose of clothing while receiving monetary compensation. Consumers can sell their clothing to bricks-and-mortar consignment shops, for instance. A consignment shop sells second-hand clothing from individuals and charges a fee or percentage of the profits. Traditionally, consignment stores have certain criteria for the merchandise they will accept and may charge higher prices for the goods. Or, if consumers prefer, they could attempt to sell their clothing themselves through a 
newspaper advertisement or by hosting a garage sale. Many individuals attempt to sell their clothing on the Internet on a site like e-Bay. The purpose of all of these second-hand transfer outlets can be for purely economic gain but many focus on the environmentally responsible act of not throwing things into landfills.

Giving clothing away to friends or family is common and has been looked at as a popular disposal method (Lastovicka \& Fernandez, 2005; Mitchell et al., 2009; Winakor, 1969). The decision to give to friends and family has been noted as being more popular among older people while younger people donate to charities in higher numbers (Mitchell et al., 2009) . Data does not exist on the exact amount of clothing that is given within personal circles but the amount that is donated to charity is likely to exceed the amount. Each year charities received millions of pounds of unwanted clothing (Shim, 2010). Individuals have various methods for disposing of their unwanted clothing. Since clothing typically possesses personal meanings to owners, sometimes the process of disposition can be difficult (McCracken, 1986). No matter the disposal option, certain rituals have been examined that can ease the disposal process (Lastovicka \& Fernandex, 2005).

Divestment Rituals during Disposition

Passing the clothing item from the original owner to a new owner necessitates a divestment process that requires special actions on the part of the original and new owners. McCracken (1986) stated that cultural meanings are placed on consumer goods and that clothing as a consumer good is particularly complex. According to McCracken (1986), when clothing is transferred so too is the meaning that the clothing held. Original 
owners may not want to pass along the personal meanings to the following consumer; likewise the second consumer may not want to obtain personal meanings placed on the clothing by the previous owner. Prior to disposal of clothing, previous meanings must be eradicated which is accomplished through the ritual of divestment. McCracken (1986) states that divestment rituals have two purposes. Firstly, the original owner will engage in practices to erase the meanings that they have placed on the clothing. Secondly, the second consumer will engage in practices to erase the meaning associated with the original owner. The goal of erasing the original meanings is wanted by both parties and it is important for both parties to take part in the activity (McCracken, 1986). For example, before selling clothing the original owner may have the item cleaned. Likewise, after purchasing a second-hand piece of the clothing the second consumer will also have it cleaned.

The divestment ritual enables both parties to avoid contamination. Contamination can be positive or negative and can be real or imagined (Roux \& Korchia, 2006). Positive contamination results from obtaining and wearing a piece of clothing that holds special meaning. It is common for wedding attire to be passed down from mothers to daughters. Research in wedding dress disposal has uncovered that brides often sell their wedding gowns to share the positive feelings they have about their wedding day and subsequent marriage (Yurchisin \& Whitenack, 2007). Similarly, clothing may be disposed of to rid owners of negative memories associated with the clothing item (Lastovicka \& Fernandez, year). Brides who had negative feelings about their wedding day or marriage mentioned disposing of their wedding gowns to liberate themselves from these negative emotions 
(Yurchisin \& Whitenack, 2007). Thus, negative contamination can be a function of the symbolism associated with a particular clothing item.

Negative contamination does not necessarily need to be related to symbolism, though. Clothing may literally be contaminated with dangerous or hazardous materials. For instance, second-hand clothing has recently been linked with bed bug infestations (Mims, 2011). Due to the closeness to the body, a fear of disease transfer is legitimate and for that reason undergarments are typically exempt from the second-hand market. However, outerwear and other garments that are further from the body create less fear of contamination from consumers.

The decision for clothing disposition is comprised of decisions as to how and where to dispose of the clothing (Jacoby et al., 1977) as well as decisions about coping with the disposition which can lead to divestment rituals (McCracken, 1986). While many methods of disposition exist, donating to charity seems to be the most popular method (Birtwistle \& Moore, 2007). While researchers (Bianchi \& Birtwistle, 2010; HaBrookshire \& Hodges, 2008; Mitchell et al., 2009) have suggested that consumers may donate apparel to charitable organizations for utilitarian and hedonic reasons, the motivations of donors, particularly the social psychological factors that may affect donors' motivations, require further investigation. 


\section{Motivations for Donating Clothing to Non-Profit Thrift Stores}

Hanson’s (1980) Paradigm of Consumer Product Disposition Process is based on Engel et al.'s (1968) consumer decision-making model. Figure 4 presents Hanson's (1980) model. Hanson (1980) argues that consumers determine what to dispose of and what to purchase using a similar series of steps. The disposition process begins with problem recognition which is a compilation of factors based on the situation, object and person (Hanson, 1980). With clothing disposal, the clothing is the object and the situation can represent the environment or context in which the clothing was used. These components make up the external stimuli whereas the personal factors are the unique characteristics of the individual. During the second stage, information is gathered and evaluated to determine the disposition method and location. For example, often nonprofit donation sites offer easy access for donation. The ease and visibility of donation sites have been reported as significant criteria for donation as a disposal option (Mitchell et al., 2009). This then leads to the actual disposition behavior which can include options from the Jacoby et al. (1977) model. The subsequent attitudes and evaluations after disposition make up the post-disposition outcomes.

If the disposition decision-making process mirrors the acquisition decisionmaking process, as Hanson (1980) suggests, it seems likely that other aspects of the acquisition process would also be reflected in the disposition process. One aspect of the acquisition process that may also be present in the disposition process is consumer motivation. Hence, Babin et al.’s (1994) conceptualization of utilitarian and hedonic 
motivation may also apply to the disposition process in a manner similar to the acquisition process.

Figure 4: Disposition Process

Problem

Recognition
Search/

Evaluation
Disposition

Decision
Post

Disposition

Outcomes

Source: Hanson (1980)

The work that several researchers have completed about disposition and donation behavior lends support to this supposition. In their study, Lastovicka and Fernandez (2005) demonstrated that disposition can be an emotional process. Because everyone in Lastovicka and Fernandez's (2005) study was selling, as opposed to donating, the unwanted items, the disposition process was, at least in part, motivated by economic, utilitarian desires. At the same time, however, individuals selling items at garage sales and on the Internet mentioned that they had difficulty ridding themselves of particular items because these items had special, positive meanings for them. To aid in the transfer of ownership of the item, individuals attempted to retain some of the positive emotions associated with the item by sharing the item with another person. That is to say, the individuals disposing of the items felt they were passing the positive meanings on to the next owner of the item. In this way, the original owners felt good about parting with the item because, by doing so, they were allowing the new owners to experience the positive 
aspects associated with the item. Thus, the disposition process was an emotionally charged, hedonic experience for the individuals disposing of the items.

While Lastovicka and Fernandez (2005) found that selling items can be a hedonic or utilitarian experience, other researchers have investigated how donation behavior can be a hedonic or utilitarian experience. Although they were not investigating clothing donation behavior in particular, Bendapudi et al. (1996) researched the helping decision making process which includes (1) perception, (2) motivation, (3) behavior, and (4) consequences. They found that a positive relationship exists between an individuals' perception of an organization and their motivations to help the organization. Likewise, this can lead to more helping behavior and more positive consequences. Bendapudi et al.'s (1996) study suggests that individuals can be motivated to donate for different reasons. Some of these reasons may be utilitarian in nature, as donations can be taxdeductible and save individuals money. Some of these reasons may be more hedonic because making donations allows the individuals to feel good about themselves as they help others in need. If we consider clothing donation to be helping behavior in the same way that donating money or donating time can be helping behavior, Bendapudi et al.'s (1996) study lends support to the notion that individuals may donate clothing for different reasons, some of which may be hedonic and others may be utilitarian.

While the work of Lastovicka and Fernandez (2005) and Bendapudi et al. (1996) was not specifically about clothing donation behavior, the findings from several studies about clothing donation behavior are consistent with the studies about general disposition and donation behavior. Many individuals who donate clothing to charitable 
organizations' thrift stores do so for altruistic reasons, such as trying to protect natural resources (Bianchi \& Birtwistle, 2010) or helping fellow community members in need (Mitchell et al., 2009). Others donate to charitable organizations to relieve the guilt associated with overconsumption (Ha-Brookshire \& Hodges, 2008). In addition to these emotional motivations associated with clothing donation, individuals also mentioned that they donated unwanted clothing in an effort to clean out their closets, which represents a more practical motivation for donating clothing to charitable organizations' thrift stores (Ha-Brookshire \& Hodges, 2008; Mitchell et al., 2009). Because donors seem to be motivated by both emotional and practical reasons, it seems likely the utilitarian/hedonic motivation conceptualization applies to the clothing donation process as well as the purchasing process for second-hand clothing.

What is not clear from previous studies about donors of clothing to charitable organizations' non-profit thrift stores is the way in which demographic and social psychological factors may influence the specific motivations that drive donors' behavior. Hibbert, Horne, and Tagg (2005) did research the demographic characteristics likely to affect the channel of disposition used by consumers. Hibbert et al. (2005) found that demographic characteristics, such as income, age, and number of children living at home, did have an impact on the ways in which consumers chose to dispose of unwanted goods. However, when examining the disposal method used for unwanted men's and women's clothing, the researchers found that donation to charitable organizations' thrift stores was the most prevalent channel used regardless of any demographic characteristics. Hence, demographic characteristics do not seem to impact disposition method selection. 
However, if donation behavior is similar to purchase behavior, then it seems likely that perhaps both demographic as well as social psychological factors would affect the motivation driving consumers' donation behavior. It may be the case that some of the same social psychological factors influence the same consumers' motivations for both donation behavior as well as second-hand clothing purchase behavior.

The Relationship between Purchase and Donation Since an estimated $85 \%$ of people donate items to charity annually (Mitchell et al., 2009) and $15 \%$ of people purchase second-hand items annually (NARTS, n.d.), it is plausible to predict an overlap of donors and consumers exist. Yet no research has specifically been done to see if these two behaviors are done by the same people. The relationship between purchasing and disposing is not known. Typically, the purchasing stages are studied separately from the disposition stages. One notable exception is Albinsson and Perera (2009) who examined women's behavior at a clothing exchange event. However, Albinsson and Perera (2009) focused on the disposition process and the modes of disposition. Their findings supported those of other researchers (Bianchi \& Birtwistle, 2010; Ha-Brookshire \& Hodges, 2008; Mitchell et al., 2009) who found that individuals donate clothing to charitable organizations for hedonic, altruistic motives as well as utilitarian, space-saving motives. Although Albinsson and Perera (2009) interviewed individuals who were participating in the clothing exchange event, they did not discuss the relationship between clothing disposition and acquisition with their participants. Instead, the research focused primarily on disposition motives. The motives 
that one individual has for donating and purchasing second-hand clothing from a charitable organization's store have not been examined. Furthermore, the factors that may influence the motivations that one consumer has for purchasing second-hand clothing from and donating clothing to a charitable organization's thrift store have not been explored.

Examining disposition and purchase motives offers a richer understanding of the complete process of clothing consumer behavior (Denegri-Knott \& Molesworth, 2009). As the models of the clothing consumer decision-making process depict (Engel et al., 1968; Winakor, 1969), the consumption process does include activities post-purchase, even if little research has been done in this area. And due to the increase in second-hand clothing purchase, the consumer decision-making process models featuring exclusively new clothing are no longer applicable. Instead, a closed-loop system where castoff clothing re-enters the supply chain in some form is needed for today's marketplace (Kumar \& Malegeant, 2006).

Additionally, from a practitioner's standpoint, understanding donors' motivations and second-hand clothing purchasers' motivations will help them better target each group. Because managers of charitable organizations' thrift stores rely on both donors and purchasers to earn money to fund community programs, understanding the reasons behind donation and purchase behavior is particularly important for them. Furthermore, being able to take advantage of any synergies that may exist between donors and purchasers in terms of motivations for behavior is beneficial for the business. Thus, research needs to be conducted in a context in which individuals can be both donors and 
purchasers. One context in which donors and purchasers come together is the Junior League Rummage Sale.

This sale provides a large-scale venue in which second-hand clothing can be donated by and purchased by the same participants. By investigating both donation and consumption patterns of individuals in the same context, a richer understanding of the motivations and factors influencing motivations may be uncovered. And, because members of the Junior League of Winston-Salem are women, who are responsible for the majority of clothing consumption decisions within the household (Gogoi, 2005), the information gleaned from their discussions about their purchase and donation behavior of second-hand clothing at the Rummage Sale could be useful to other charitable organizations that operate retail outlets that sell donated clothing.

\section{Summary}

This chapter included a review of literature involving pertinent information. Research on second-hand clothing purchase and clothing donation was discussed. The possible hedonic and utilitarian motivations for purchasing and donating were identified. Factors influencing those motivations were also discussed. The next chapter will describe the methodology that will be used in the study. 


\section{CHAPTER III METHODOLOGY}

This chapter includes the methodology used in this research. The research design, participant selection, and interview method used are discussed.

\section{Research Purpose}

The purpose of this research was to investigate the motives of second-hand clothing consumers who both purchase from and donate to the store associated with one charitable organization. More specifically, individuals' motivations for donating clothing were compared to their motivations for purchasing second-hand clothing from the same location using the hedonic/utilitarian framework. Furthermore, the demographic and social psychological factors affecting individuals' motivations for donating to and purchasing second-hand clothing from one charitable organization's retail outlet were examined.

Ordinarily, the second-hand clothing purchase process and the clothing donation process occur at two different times and in two different contexts. However, at some times and in some contexts, individual consumers may experience aspects of both clothing disposal and clothing purchase simultaneously. The Rummage Sale hosted by the Junior League of Winston-Salem represents one of those times and one of those contexts. 
This research was designed to uncover information about individuals who partake in both donation and consumption of second-hand clothing through interviews with members of the Junior League who attended the Rummage Sale. Little research has been conducted in the area of clothing donation and second-hand clothing purchase, and no research could be located in which both processes were examined in the same study. The present study aimed to see if there is a connection among the two processes.

\section{Objectives}

The objectives of this study included:

1) To explore second-hand clothing consumers' motivations (e.g., hedonic, utilitarian) for purchasing clothing from the retail outlet associated with one particular charitable organization (i.e., Junior League Rummage Sale).

2) To examine the demographic (e.g., age, income, marital status) and social psychological factors (e.g., eco-consciousness, need for uniqueness, price consciousness) that may have an impact on consumers' motivations for purchasing second-hand clothing from the retail outlet associated with one particular charitable organization (i.e., Junior League Rummage Sale).

3) To uncover second-hand clothing consumers' motivations (e.g., hedonic, utilitarian) for donating clothing to the retail outlet associated with one particular charitable organization (i.e., Junior League Rummage Sale).

4) To investigate the demographic (e.g., age, income, marital status) and social psychological factors (e.g., eco-consciousness, need for uniqueness, price 
consciousness) that may have an impact on consumers' motivations for donating clothing to the retail outlet associated with one particular charitable organization (i.e., Junior League Rummage Sale).

5) To identify the relationships that exist, if any, between second-hand clothing consumers' motivations (e.g., hedonic, utilitarian) for purchasing from and donating to the retail outlet associated with one particular charitable organization (i.e., Junior League Rummage Sale).

6) To explore the relationships that exist, if any, between the factors (i.e., demographic and social psychological) that influence second-hand consumers' motivations (e.g., hedonic, utilitarian) for purchasing from and donating to the retail outlet associated with one particular charitable organization (i.e., Junior League Rummage Sale).

\section{Research Design}

Qualitative research using in-depth interviews was used for this project. Due to the lack of previous research in this area, the research was exploratory in nature. Only a limited amount of research exists about the disposition process and the consumption of second-hand clothing and even less research exists that pertains to both practices being studied in the same context. This study provides insights into both of these processes as well as look for a connection between them.

Because the purpose of this study was to gain a deeper understanding of the complex relationship that may exist between consumers' motivations for donating 
clothing to and purchasing clothing from one retail location, face-to-face in-depth interviews were used to uncover information about the clothing donation and secondhand clothing consumption experience of participants. Interviews enabled the researcher to gain a deep understanding of experiences and events from the participants' perspective (Holloway \& Jefferson, 2000; Rubin \& Rubin, 1995; Schouten, 1991; Seidman, 1998). Open-ended questions were developed so that the participants could divulge as much information about their experiences as possible (Patton, 2002). An interview schedule was created to guide the interview process (see Appendix A). The questions included topics pertaining to the research objectives. Some questions focused on donation and others focused more on second-hand clothing purchase. Some questions were asked specifically about the Rummage Sale but the opportunity to elaborate about other experiences in second-hand markets was also available.

\section{Participant Selection and Data Collection}

Participant selection revolved around the Rummage Sale event which took place during the week of April 4-9, 2011. Participants were purposively selected based on their behavior at the Rummage Sale. Participants who both donated clothing to and purchased clothing from the Rummage Sale qualified for participation in the study. During the event, the researcher recruited participants and checked their eligibility by asking them if they both purchased clothing from and donated clothing to the Rummage Sale. Additionally, possible participants were emailed and asked about eligibility and willingness to participate. 
Participants who agreed to be involved in the research project were contacted in May and interview times were set up and took place in June and July of 2011. Face-toface interviews were conducted at a time and location specified by the participant. The interviews followed a semi-structured format. As data collection proceeded, some of these questions were altered or omitted and other questions were added because an emergent intuitive design was used that allowed the data collected during each interview to guide subsequent interviews (Marshall \& Rossman, 1999). A combination of main questions, follow-up questions, and probes allowed the interviews to be detailed and vivid (Rubin \& Rubin, 1995). A short questionnaire was used to collect demographic information at the completion of the interview. The demographic questionnaire is included in Appendix B.

Only women were targeted for this research project. The Junior League of Winston-Salem is an organization whose members are exclusively females. Therefore, mainly women were volunteering at the event and donating the clothing. The Rummage Sale is open to all but the attendance was predominantly made up of women. So it was reasonable to predict that the majority of shoppers would also be women. Women are responsible for the majority of the household purchases (Peters, 2003; Underhill, 2009). For these reasons, focusing on the donation and consumption practices of women for this exploratory project allowed the experiences of those most likely to engage in both behaviors to be examined.

Thirty-five potential participants were contacted for participation in the study and a total of 18 interviews were conducted. This sample size was appropriate given that the 
goal of the interviews was to obtain a deep, rich understanding of the motives for secondhand clothing purchase and donation behavior. This number of participants allowed a range of responses to be represented before data saturation occurred and no new information was revealed by the last interview. Each interview lasted approximately 30 to 90 minutes and was audio recorded.

\section{Data Analysis}

Upon completion of each interview, interview data was transcribed verbatim. The data was then organized and analyzed. Coding the data included reviewing the interviews to uncover the meanings, concepts, and themes within them. Using an emergent intuitive design, data analysis began immediately after the first interview was completed. Each interview transcript was read in its entirety several times and key phrases of possible theoretical import were bracketed (Seidman, 1998). Key phrases that share some commonality were grouped together as conceptual categories, and these categories were used to help determine the direction of the remaining interviews (Marshall \& Rossman, 1999). Each subsequent interview was analyzed in the context of previously gathered data and examined for points of similarity or dissimilarity. Existing categories were amended and new categories were created to incorporate all of the data of theoretical import. Once all interviews were completed, the final categories were examined for any potential linkages that existed among them (Rubin \& Rubin, 1995). Multiple categories that were theoretically linked were expanded into broader, overarching themes. These themes were used to answer the research questions set forth prior to data collection. 


\section{Summary}

In this section, the methodology of this research project was explained. Interview data was discussed at the primary data collection tool. The research design and participant sample were described. The following chapter will present the data collected and the interpretation of the data. 


\section{CHAPTER IV}

\section{INTERPRETATION}

In this chapter, information concerning the characteristics of the participants and data analysis procedures used for the study is presented. The principal emergent themes from the qualitative interviews are discussed. The chapter is divided into two parts: a) a description of the demographic characteristics of participants and b) the thematic interpretation of the interview data.

\section{Participant Demographic Characteristics}

The number of participants in this study totaled 18 adults (pseudonyms and demographic data are provided in Table 1. Participants' age ranged from 24 to 64 . They had all graduated from college, and some had completed graduate school. Three quarters of the participants were married and nearly half had children under the age of 18 living at home. All but one of the participants indicated earning personal income with a median income from $\$ 60,000-\$ 79,999$ annually. Additional demographic information is contained in Table 1. All of the participants were involved with the Junior League of Winston-Salem but had varying levels of involvement and had been involved for a varying number of years. The years of attending the Rummage Sale ranged from one to thirteen with a mean of five and a half years. The number of participants, 18 , was sufficient to reflect variations in participants' experiences based on the length of time 
they had been involved with the organization and their varying roles in the organization (e.g., president, board member, Rummage Sale committee member, first year member). Additionally, no new information came out during the 18th interview.

Table 1

Demographic Characteristics of Participants

\begin{tabular}{|c|c|c|c|c|c|c|}
\hline Name & Age & Income & Children & $\begin{array}{l}\text { Years of } \\
\text { participation }\end{array}$ & Donated & Purchased \\
\hline Anita & 28 & $\begin{array}{l}\$ 40,000- \\
\$ 59,000\end{array}$ & 0 & 1 & $\begin{array}{l}\text { Assorted } \\
\text { clothes }\end{array}$ & $\begin{array}{l}\text { Skirts for } \\
\text { work }\end{array}$ \\
\hline Belle & 52 & $\begin{array}{l}\text { Over } \\
\$ 80,000\end{array}$ & 1 & 1 & $\begin{array}{l}\text { Children's } \\
\text { clothes }\end{array}$ & Vintage dress \\
\hline Claire & 30 & $\begin{array}{l}\text { Over } \\
\$ 80,000\end{array}$ & 0 & 5 & Own clothes & Necklace \\
\hline Danielle & 24 & $\begin{array}{l}\$ 20,000- \\
\$ 39,000\end{array}$ & 0 & 1 & $\begin{array}{l}\text { Assorted } \\
\text { clothes }\end{array}$ & $\begin{array}{l}\text { Designer } \\
\text { clothes }\end{array}$ \\
\hline Ellie & 30 & $\$ 0$ & 1 & 5 & $\begin{array}{l}\text { Family's and } \\
\text { own clothes }\end{array}$ & $\begin{array}{l}\text { Children's } \\
\text { clothes, } \\
\text { draperies }\end{array}$ \\
\hline Fran & 33 & $\begin{array}{l}\text { Over } \\
\$ 80,000\end{array}$ & 2 & 6 & $\begin{array}{l}\text { Children's and } \\
\text { own clothes }\end{array}$ & $\begin{array}{l}\text { Designer } \\
\text { dress }\end{array}$ \\
\hline Gwynne & 31 & $\begin{array}{l}\$ 40,000- \\
\$ 59,000\end{array}$ & 2 & 5 & $\begin{array}{l}\text { Assorted } \\
\text { clothes }\end{array}$ & $\begin{array}{l}\text { Clothes for } \\
\text { children }\end{array}$ \\
\hline Hannah & 64 & $\begin{array}{l}\text { Over } \\
\$ 80,000\end{array}$ & 0 & 10 & $\begin{array}{l}\text { Assorted } \\
\text { clothes }\end{array}$ & $\begin{array}{l}\text { Designer } \\
\text { purse, dress }\end{array}$ \\
\hline Ivy & 28 & $\begin{array}{l}\$ 60,000- \\
\$ 79,000\end{array}$ & 0 & 3 & $\begin{array}{l}\text { Family } \\
\text { members' } \\
\text { clothes }\end{array}$ & Fur stole \\
\hline Julie & 26 & $\begin{array}{l}\$ 40,000- \\
\$ 59,000\end{array}$ & 0 & 6 & Own clothes & $\begin{array}{l}\text { Clothes and } \\
\text { linens }\end{array}$ \\
\hline Kristen & 34 & $\begin{array}{l}\$ 20,000- \\
\$ 39,000\end{array}$ & 2 & 5 & $\begin{array}{l}\text { Assorted } \\
\text { clothes }\end{array}$ & $\begin{array}{l}\text { Clothes for } \\
\text { self/ children }\end{array}$ \\
\hline
\end{tabular}




\begin{tabular}{|lllllll|}
\hline Lauren & 35 & $\begin{array}{l}\text { Over } \\
\$ 80,000\end{array}$ & 2 & 12 & $\begin{array}{l}\text { Children's and } \\
\text { own clothes }\end{array}$ & $\begin{array}{l}\text { Shoes, } \\
\text { children's } \\
\text { clothes }\end{array}$ \\
\hline Mary & 50 & $\begin{array}{l}\text { Over } \\
\$ 80,000\end{array}$ & 0 & 13 & $\begin{array}{l}\text { Assorted } \\
\text { clothes }\end{array}$ & $\begin{array}{l}\text { Clothes for } \\
\text { self and } \\
\text { nephews }\end{array}$ \\
\hline Nicole & 38 & $\begin{array}{l}\text { Less than } \\
\$ 20,000\end{array}$ & 2 & 6 & $\begin{array}{l}\text { Children's and } \\
\text { own clothes }\end{array}$ & $\begin{array}{l}\text { Clothes for } \\
\text { costumes }\end{array}$ \\
\hline Olivia & 41 & $\begin{array}{l}\$ 60,000- \\
\$ 79,000\end{array}$ & 0 & 4 & $\begin{array}{l}\text { Assorted } \\
\text { clothes }\end{array}$ & $\begin{array}{l}\text { Scarves, } \\
\text { purses }\end{array}$ \\
\hline Piper & 24 & $\begin{array}{l}\$ 20,000- \\
\$ 39,000\end{array}$ & 0 & 2 & Own clothes & $\begin{array}{l}\text { Designer } \\
\text { clothes }\end{array}$ \\
\hline Rachel & 31 & $\begin{array}{l}\$ 60,000- \\
\$ 79,000\end{array}$ & 0 & 7 & Own clothes & Suits \\
& & & & & & \\
\hline Sam & 39 & $\begin{array}{l}\$ 40,000- \\
\$ 59,000\end{array}$ & 2 & 7 & $\begin{array}{l}\text { Assorted } \\
\text { clothes }\end{array}$ & $\begin{array}{l}\text { Children's } \\
\text { clothes }\end{array}$ \\
\hline
\end{tabular}

Note. All names used in this table are pseudonyms.

Thematic Interpretation

The responses of the 18 women who participated in the interviews suggested that they both donated to and purchased from the Rummage Sale for both utilitarian and hedonic reasons. Although previous researchers have found that both demographic and social psychological characteristics affected the motivations of second-hand clothing purchasers and donors, primarily social psychological characteristics seemed to be influential with this sample of participants. Patterns were identified between the characteristics impacting the motivations for purchasing and donating. Several themes emerged from the study. These themes are discussed below. 


\section{Motivation for Purchasing}

\section{Hedonic Purchasing-Emotional Thrifters}

The responses of approximately half of the respondents seemed to indicate that they primarily shopped at the Rummage Sale in a hedonic fashion. Their responses contained words, phrases, or examples of actions that suggested that they enjoyed the experience of shopping at the Rummage Sale. Because these individuals shopped at the Rummage Sale to fulfill emotional needs, this group of respondents was referred to as emotional thrifters.

For example, Danielle discussed how excited she got at the Rummage Sale. Currently, Danielle is trying to be more fiscally responsible because she is young and is just starting out on her own. However, she admitted that when she saw all of the merchandise, she could not control herself. She stated that

it [the Rummage Sale] was during a week when I was like, "You need to watch your money if you're going to buy something. Instead of buying a bunch of little purchases, you should save up for something nice. Stop eating out all the time." I think I was feeling guilty about all of those lifestyle purchases so I said, "Don't go nuts at the Rummage Sale boutique." But then I got there and I saw how discounted everything was and, of course, I walked out with five things. (Danielle)

As the quote illustrates, although Danielle is trying to follow a budget and be more organized and careful about her clothing purchases, the excitement she feels when seeing all of the merchandise makes her behave in an unplanned manner. One negative consequence of this emotional shopping is that Danielle cannot remember what she bought at the Rummage Sale. First she stated, 
I gave myself guidelines so that I wouldn't go nuts. Like work tops and things that are appropriate to wear to the office in the spring. I stuck to that for the most part. But I'm pretty sure I got a sweater. (Danielle)

And later, she mentioned, "I remember getting a silk Banana Republic sleeveless top and some striped sweater and...I can't remember now what I got."

Even though Danielle is attempting to be more cognizant of her spending habits, she seems unable to follow her own buying guidelines. Unfortunately, this shopping behavior makes her feel guilty. Regardless of her post-purchase emotional reaction, her behavior at the Rummage Sale suggests that she also experiences strong emotions, such as excitement and pleasure, while shopping.

Another example of a respondent who mentioned the emotional aspects of shopping at the Rummage Sale is Fran. Fran discussed how much enjoyment she had shopping at the Rummage Sale for herself and her two children. When asked if she went to the sale looking for anything in particular, she stated,

Well, I always just like to look. Because there is always something that is fun that I just really want. I think it's a good deal. Actually yes, I went in, I like to get, to see if there is anything fun for my kids. Because I think it's a good place to get kids' clothes.... So, yeah, I was mostly going in looking for that I ended up getting some pajamas and some shorts and a beach hat and stuff like that for my kids. (Fran)

Later, Fran mentioned that she also purchased "a couple of things" for herself, including a Diane von Furstenberg dress that she described as "great". Although Fran did plan to purchase clothing for her young children because it was affordable, she also ended up purchasing a designer dress for herself while browsing through the various 
departments at the Rummage Sale. It seems to be the case that Fran received pleasure from attending the Rummage Sale and making purchases for herself and her children. While, like Danielle, Fran mentioned the price of the merchandise that she purchased, the inexpensive price tag seemed to be an incentive to purchase the merchandise she found that she liked during the sale, but the low price was not the only reason she wanted to shop there. Neither Fran nor Danielle mentioned that they made a budget of a specific amount for the Rummage Sale. And, even though the amount of disposable income both Fran and Danielle had may have been limited, neither woman stated that she had to shop for apparel at the Rummage Sale because she had no other options available. Both women seem to have been excited by finding apparel items that they wanted, but did not need, at low prices.

In addition to experiencing positive emotional reactions from browsing through and purchasing the second-hand apparel that was available at the Rummage Sale, several of the respondents also mentioned that they liked shopping at the Rummage Sale because it provided them with an opportunity to socialize with their friends and family members. For example, Fran discussed how she and her mother made an event of the Rummage Sale:

So, my mom and I like to shop and we like to shop deals. Like, I'm not afraid to dig in a box for something. I'm one of those people that thinks it's fun. And my mom is, too. She likes the Preview Party [evening of shopping before the Rummage Sale officially starts] and she likes the hunt, too. So she went with me and we scouted out some things that we wanted. She had actually gone to the Sustainer Breakfast, which is before the Preview Party. Because I had been working that week [sorting items for the Rummage Sale], she said, "If there's anything you really want that you think will get bought, let me know because I'm going to the Sustainer Breakfast." So I did. (Fran) 
It seems to be the case from her statement that Fran likes to shop at the Rummage Sale with her mother because it is an enjoyable event for them. The Rummage Sale offers the two women a chance to bond with each other as they sort through the boxes of goods available for purchase.

Like Fran, Anita mentioned that she liked to go shopping at the Rummage Sale with friends. In addition to bonding, Anita also enjoyed shopping with friends because they helped her select the appropriate items to purchase. The following exchange between Anita and the researcher illustrates this point:

Anita: I would say I went in a group because I was there with friends. Because when I was picking out items, I was showing it to other people and getting their opinion.

Researcher: So was it a social interaction?

Anita: Yeah, and I would say even more so in that environment I wanted other people's opinions than going to a new shop. It's different when you're looking at it there and you're like, "Does this look good?" Or, "Have I just been staring at old clothes for so long that this just looks good?" So it was nice to have another opinion. (Anita)

Anita's discussion highlights the importance of others in the shopping experience.

Friends help her avoid making mistakes and purchasing clothing that is not appropriate.

This exchange also brings up the issue of clothing involvement. Anita's statements seem to suggest that she worries about the social risk associated with purchasing and wearing the wrong items. Appearance is definitely important to Anita, as well as the other emotional thrifters. 
It seemed to be the case that emotional thrifters were not only hedonic in their approach to the Rummage Sale, but that they tended to shop hedonically for their clothing during other purchasing occasions as well. For instance, Piper talked about shopping hedonically at other second-hand clothing stores with her mother:

I love to find a good deal. I love to see a really good price on a pair of jeans because I apparently need all of these jeans. But I love to find a good price. My mom and I hate to buy at retail prices. So, we always scan around for something good, and find, like, really good.... Like, we both like Tory Burch, so if we find Tory Burch shoes for a good price, it's hard to pass up. So, it's more of the hunt for us. We just get really excited. And if I find something for her, it's fun. (Piper)

Here, Piper mentions not only the thrill of the hunt, but also the pleasant social aspects of shopping.

The pleasant experience of the Rummage Sale has kept Hannah coming back, as this was her tenth year shopping at the Rummage Sale. Hannah describes the experience she has had with second-hand clothing shopping over the years. It is apparent that it is something she enjoys and derives pleasure from:

I used to live in New York and there were ones there that models would sell their clothes to that they had worn modeling. People who were very wealthy in Westchester, New York would sell their clothes to [these stores]. That was so much fun. That's where I really got started as a teenager. And so you would get designer names and couture things. That was so cool. And furs...it was very cool. So yeah, I will go to some of those, but a lot of them here [in Winston-Salem] are just junky. So I go to ones that have high quality. (Hannah)

Hannah's quote also shows that other attributes, like the quality of the merchandise available, is a factor in her second-hand clothing shopping decisions. While Hannah is primarily hedonic in her shopping, she is drawn to higher quality items, again suggesting 
an interest in or involvement with clothing as a product category. She feels that she knows what represents high quality for apparel products, and she is willing to buy second-hand clothing and to make several trips to several different stores, including the Rummage Sale, to purchase the best clothing available.

While many of the respondents could be classified as more hedonic in nature in terms of their purchase behavior at the Rummage Sale, not all of the women interviewed believed that the Rummage Sale engendered a positive emotional response for them. Participants who focus more on the function and purpose of their shopping at the Rummage Sale are described next.

Utilitarian Purchasing--Specific Thrifters

Approximately half of the respondents mentioned words, phrases, or actions that suggested that their purchasing at the Rummage Sale was utilitarian in nature. These individuals were very organized and methodical in their shopping, looking for particular items at the Rummage Sale. They did not mention that they enjoyed the experience of shopping at the Rummage Sale. Their satisfaction seemed to come only after they purchased the specific item that they needed to purchase. As such, these utilitarian respondents were termed specific thrifters.

Nicole is a specific thrifter. She stated that she knew exactly what she was looking for at the Rummage Sale, and that is what she ended up purchasing. According to Nicole,

I like to go through it by myself. And honestly, I didn't make that much of an effort to go look at the merchandise. If I happened to notice something as I was placing things out, I made a couple of notes of things that I may be interested in if 
they were still there. But I didn't actively go shopping. I was looking for a specific pair of shoes for a costume that I needed later on in the year and was successful in that. But other than that, I didn't...just want to go shopping and see what is out there. (Nicole)

As Nicole's quote suggests, she did not do much browsing at the Rummage Sale.

Instead, she had an idea about what she wanted to purchase, and that was the only item that she actively sought out. For Nicole, this pattern of utilitarian purchasing at the Rummage Sale is a consistent one. She related a story about the previous year which again supports the notion that she is a specific thrifter:

I've purchased a few things, specific things that I went in looking for in my mind. I've never just walked up and saw something and said, "Oh, that's neat. I'll buy it." Maybe with the exception of a holiday ornament or something. Like one year, I bought a wreath, an Easter egg wreath. I didn't look for that intentionally but I bought it. But the things in the past have been specific things that I have been looking for, and usually they are for this event that I need them for or some other thing that is coming up and I need something for. For example, there was a Steeple Chase that was held last year. And I was working the Steeple Chase, so I needed a hat and didn't want to put too much money into a hat because I was going to be working on a hot day. But I happened to notice that they had really great hats in the boutique section [of the Rummage Sale], so my husband actually ended up coming to the Preview Party and he bought it that night for me while I was working in another department. (Nicole)

Although Nicole could not know exactly what items would be available for purchase at the Rummage Sale before attending, her statements seem to indicate that she has some general idea about what she would like to purchase before she attends the event. Then, at the event, if she sees an item that will work for her purpose, she will purchase it. But her quotes do not reveal that she is an impulse buyer or that she necessarily enjoys the thrill of the hunt, as some of the emotional thrifters' statements seemed to suggest. 
Similarly to Nicole, Gwynne also seemed to be utilitarian in her approach to shopping at the Rummage Sale. Gwynne has two young boys, a one-year-old and a threeyear-old. She stated that she was "always on the lookout for cute clothes for them" (Gwynne). As such, she did end up purchasing about 20 items of clothing for her two boys at the sale. She did not, however, purchase anything else. When asked if she ever purchased clothing for herself at the Rummage Sale, Gwynne stated,

No, I haven't. That ladies clothing department is just overwhelming to me. I've not even gone to that department since my provisional year [in the Junior League] and I had to work in there. I just haven't gone for myself but for my little boys. They trash their clothes when they go to daycare in them or when they're on the playground. They get spaghetti stains on them and I don't feel as bad just letting them wear those clothes out and them tossing them. I save their nicer outfits for other stuff, besides school. So that's kind-of why I got stuff from there. (Gwynne)

Gwynne's remarks suggest that she does not particularly enjoy being surrounded by clothing that she could purchase for herself. She does not seem to find the experience as exciting as some of the other respondents do. Interestingly, she, like other specific thrifters, tends to be utilitarian in her other shopping endeavors, as well. Gwynne stated that she usually goes shopping by herself when she is planning to purchase clothing for herself. According to Gwynne,

If I'm travelling with somebody, then, yeah, it's fun to shop with girlfriends. But if I just need something, it's faster just for me to go by myself. (Gwynne)

For Gwynne, a successful shopping trip is one in which she leaves the store with the specific item she planned to purchase. Shopping is not a fun, recreational activity, unless she is already in a relaxed state of mind, such as when she is on vacation. 
The same seems to be true for both Julie and Kristen. Julie stated,

I prefer, if I really have to buy something and I need it for this weekend or right now, like tomorrow, I really prefer to be by myself. Because I don't...I'm really like a "let's get in, let's get out" type person when it comes to shopping. (Julie)

This is not meant to suggest that Julie hates shopping or never shops with friends or family members. Instead, if left to her own devices, Julie would most likely shop for specific items by herself rather than take a shopping trip with no purchase goal in mind.

Kristen, who does shop at other second-hand clothing stores, mentioned that she is a very organized shopper:

I do shop a lot of consignment shops. So more like I'll go to a shop like that and know that I need more dresses. And then I'll...based on...well, if I go to a consignment store, it's a crap shoot whether they are going to have it or not. I'm shop savvy, I guess. (Kristen)

Here, Kristen's quote implies that she tries to plan what she is going to purchase before her shopping trip, even when she purchases second-hand clothing. Later, she stated,

I don't hate to shop, but I go for a purpose. I don't go for six hours and just browse nonstop. I'll go to one or two stores and hit them up. But if I miss out, I miss out. I'll wait for another time. I'm a power shopper. Go in, get it done, get out! (Kristen)

For Kristen, the most important aspect of the shopping trip is to satisfy the purpose of purchasing her intended item. She does not seem to enjoy browsing, and it does not seem that she is an impulse buyer. 
Hannah stated that, due to economic circumstances, she is now more of a utilitarian shopper than she used to be:

Well, in the last couple of years, I haven't shopped as much as I did in the past because we own our own business and I haven't been shopping as much because things have been hard. Now I shop maybe once when the season starts for something like one or two trendy things to update my wardrobe. Or if I see something that's a really, really good deal for something I like, that's when I'll buy it. I haven't been going browsing, you know, recreationally shopping, as much this year. I used to, but I haven't been lately. (Hannah)

Because Hannah's circumstances have recently changed, she is still a hedonic shopper at heart. So, in some ways, she is similar to emotional thrifters, in the sense that she does seem to care about her appearance and keeping up with fashion. However, other, more tried-and-true utilitarian purchasers did not seem to be as involved with their clothing or as interested in fashion as their hedonic counterparts. For instance, when asked about her favorite piece of clothing, Gwynne answered,

I don't know. I guess something that I wore out this year and had to order more pairs of online were some Old Navy skinny jeans in a really, really dark wash. I just wanted to wear those a lot. Like if we had a dress down day at work and on Saturdays and Sundays. They are comfortable and I can just throw a t-shirt on with them and go. That's probably my favorite item this year that I wore out and had to order more. (Gwynne)

For Gwynne, clothing priorities seem to be comfort and wearability. She does not seem to be worried about making a fashion mistake, like Anita who shopped with friends to reduce the amount of social risk she might face by purchasing and wearing the wrong clothing item. Gwynne does not seem to be as concerned about what others think about her clothing. She is not concerned with repeatedly wearing the same pair of pants until 
they wear out and then buying the exact same pair of pants to replace the old pair. In this sense, clothing does not seem to be as important to Gwynne as it is to some hedonic purchasers.

\section{Factors Influencing Motivation for Purchasing}

\section{Demographic Characteristics}

Because the women who participated in the interviews were relatively similar with respect to demographic characteristics, these traits did not seem to have as much of an impact as social psychological characteristics on purchase motivations at the Rummage Sale. Two factors did emerge, nevertheless, as potentially important behavioral influences.

Age. One of these factors was age of the participants. Among these respondents, the two youngest and the two oldest respondents were hedonic purchasers. These people have more time to spend browsing, not just at the Rummage Sale but at other stores. They do not have young children at home to look after, so they have greater freedom with respect to their own personal time.

When asked how often she shopped at second-hand stores, Belle mentioned "once or twice a week" (Belle). But she also indicated that she didn't buy something every time but she liked to look. At 52 years old, Belle has more time to spend leisurely and doing the activities she enjoys, which happens to be browsing at second-hand stores.

Mothers of Young Children. Another demographic characteristic that seemed to have an influence on purchasing motivation was having young children at home. The 
participants who were categorized as being utilitarian shoppers mention several different motivations for shopping at the Rummage Sale. Over half of the utilitarian shoppers have children under the age of 18 living at home. Of these, all but one indicated that they use the event to purchase clothing for their children. As a mother, these participants are responsible for most of the clothing decisions in their households and the Rummage Sale provides an avenue to get slightly used but quality clothes for their kids. While shopping for others can be a product of gift-giving, several of the mothers of young children described purchasing clothing for their children as one of their duties.

Since children grow out of the clothes quickly, many participants appreciated the fact that they could get rid of the clothes that their children could no longer wear and also get more appropriately sized clothes for them. Gwynne stated,

I just kind of, I know what size they are going to be for the next school year, and I plan their play clothes. I'll get maybe 5-10 pairs of shorts and pants and then maybe 10 short sleeved shirts, long-sleeved shirts, a mix. And then I know I'm kind of set for the next year. For preschool. (Gwynne)

Additionally, Kristen uses the Rummage Sale to buy play clothes for her two boys.

There is someone in the Junior League who has kids about 2 years older than mine. I always get their polo shirts. It has the same initials in them. Lots of polo shirts and shorts and sometimes shoes. But kids' shoes are difficult to buy secondhand because kids are rough on them. (Kristen)

While some of these women may have been utilitarian purchasers prior to having children, their current status as mothers seems to be affecting their motivation for 
purchasing at the Rummage Sale, not just in terms of the products they are purchasing but also the way in which they are purchasing those products.

\section{Social Psychological Characteristics}

Need for Uniqueness. For hedonic purchasers, the need for uniqueness seemed to be an influencing factor. For instance, when asked what type of clothing she looked for, Belle stated,

One of a kind, absolutely. And I believe in what comes in your path, in what the universe throws in your path. I enjoy that process. Yes, I absolutely enjoy the process of what I find. It's like a treasure hunt. (Belle)

Part of the reason why Belle likes the experience of shopping in second-hand stores, like the Rummage Sale, is because she can find unique things that no one else will have. Fran, another hedonic purchaser, also mentioned the joy associated with finding unique items at second-hand stores, such as consignment stores and the Rummage Sale. Concerning consignment stores, Fran stated,

I just like that you don't know what you are going to find and probably someone else isn't going to have it. I mean it's not this season I guess, obviously, because it's second-hand. But I think it's really fun to find something that's really old or something that has a lot of detail that you wouldn't necessarily find now. You can find some really great vintage things or really old. (Fran)

For Piper, a motivation for purchasing clothes is to have clothing items that others will not have. This is one of the reasons she prefers second-hand clothing over clothing that is available at mass merchandisers: 
I'm not really big on the mall because I don't like to get stuff that everybody else has. I try to look for more unique places. I really like Snob Shop, a little consignment shop. I love that place. (Piper)

She continues, "I'm eclectic, I'll try anything honestly" (Piper). It is apparent that Piper is motivated by the idea that she does not necessarily know what she will find while shopping at a second-hand store. However, she can rest assured that she will find something that few, if any, other women will be wearing this season. In this way, purchasing and wearing second-hand clothing allows Piper to express her individuality.

Mary also uses second-hand clothing as a way to find things that satisfy her personal style:

Don't get me wrong, I love new clothes but I can't always find what I like in the new clothing arena. Because I have weird taste. I like...my husband calls me a trout because I like anything shiny or glittery. I'm like, "Ahh, I have to have it!" That doesn't mean I'll wear it. Sometimes I just like to look at it. (Mary)

As the quotes illustrate, many of the hedonic purchasers at the Rummage Sale tended to also be hedonic purchasers at other second-hand outlets. Hunting for unusual products to express their individuality seemed to give them pleasure. It appears that the varied assortment of available items found at the Rummage Sale is an influential motivation for some purchasers. For those individuals who seek originality in clothing, second-hand markets offer a wider assortment of types of clothing. And for hedonic purchasers who are willing to take the time to explore and let the merchandise guide them, the Rummage Sale can be an enjoyable experience. 
Creativity. Several of the participants who were hedonic purchasers indicated the desire to repurpose items found at the Rummage Sale. The desire to use the items found at the Rummage Sale not in their current state but as the raw materials for turning into something else was mentioned by Belle. She states, "I think it's what I can turn it into later. It's the artistic aspect" (Belle). Belle uses second-hand stores to acquire the raw materials with which she can turn them into something else. She continues, "I treat them [second-hand stores] as a fabric store" (Belle).

Mary, like Belle, also liked to look for things that she could manipulate or repurpose. While showing off some of the items she had in her home, Mary stated,

This was between two sheets of paper and I cut it out and had it framed. That was in a folder. Those are Bali prints. I had them framed so they weren't anything you would have thought they could be. . . I see stuff that some people wouldn't see. This I got at Rummage but it was completely black. You would have never known, but I cleaned it. (Mary)

Mary acknowledged that she is able to look at second-hand items not for what they are but for what she can turn them into. Obviously, this is an activity that Mary enjoys to do and is one of the main reasons why she continues to shop at second-hand stores.

While previous researchers have suggested that individuals that purchase secondhand clothing are doing so because they are environmentally conscious and wish to keep clothing out of landfills, this notion of eco-friendliness did not emerge as a factor that influenced respondents' motivations for purchasing from the Rummage Sale. Instead, the respondents' desire to repurpose products seemed to be another way in which they could express their creativity and individuality. 
Price Consciousness. This year was the $57^{\text {th }}$ annual Rummage Sale. It has been a long standing tradition with a reputation of providing high quality merchandise at affordable prices. Lauren, who will be president of the Junior League next year, stated that she thought the greatest part of the Rummage Sale was the ability "to get higher quality things for a lot cheaper price." Lauren, a utilitarian purchaser, described the importance of the low prices of the merchandise. Because price is often a factor in utilitarian purchasers' decisions concerning when and where to shop, it seems logical that she would mention the low prices as an aspect of the Rummage Sale that she appreciated. This is not to say that hedonic purchasers do not like to save money. This is, rather, to suggest that, for utilitarian purchasers, the number one reason for shopping at the Rummage Sale is to take advantage of the inexpensive prices. On the other hand, for hedonic purchasers, the experience of shopping at the Rummage Sale is more important than the low prices of the merchandise.

For utilitarian purchasers, being able to buy specific brands for a low price was a benefit they received by shopping at the Rummage Sale. For example, Olivia mentioned that she likes to purchase items that are designer:

It's usually whatever I find. I found a great pair of Naturalizer shoes for \$7 and they had hardly been worn. I bought a Coach handbag before. That was kind of my first. I'm very brand oriented when I go in. We just had this discussion about brands today. Everything is usually brand-oriented. (Olivia)

Several other participants mentioned that they use the Rummage Sale as a way to purchase brands that they would normally not be able to afford. Julie mentioned the discounted prices available at second-hand stores: 
You're going to find a pair of Lily Pulitzer shorts for \$25 versus \$250. Go for it. That's just kind-of cool. I like to play golf and I don't really want to play golf in the Lily Pulitzer skort that I spent $\$ 200$ on. I'd rather play golf and get it dirty if I spent $\$ 20$ on it. That kind-of stuff. (Julie)

The importance of the price and figuring out the savings is a factor when Julie shops. She continues:

My theory is that, number one, if it has a tag on it, I mean, then that's a no brainer. But if it's in good shape and it's not stained or ripped, there's nothing visibly wrong with it, then no one is going to know the difference if you buy it $\$ 75$ less than everyone else does. (Julie)

Utilitarian shoppers tend to place a greater emphasis on the brand that is available and the price. It appears that they go through a calculation in their mind and if they feel that the brand is worth more than the price, it is an acceptable purchase. When asked if she shopped differently for first-hand clothing than for second-hand clothing, Sam replied, "Yeah, I probably look at brands more so I can figure out if I can find some steal. Yeah, I do that" (Sam). Finding a bargain or a steal was mentioned by most of the utilitarian shoppers.

Need for Convenience. The Rummage Sale is organized into 20 separate departments. It takes an entire week to set up and organize all of the merchandise for the sale which takes place over the weekend. Nicole, a utilitarian shopper at the Rummage Sale states that her favorite aspect is "probably just the convenience of it, ease of it, just because of the way it is laid out" (Nicole). It appears that the merchandising and other attributes are also important as motivations for shoppers. 
Belle, whose first time attending the Rummage Sale was this year, described the set up in this quote: "I didn't think it would be as large as it was. It was massive. Almost overwhelming. But it was well organized. I didn't think it would be that organized" (Belle).

Danielle also describes her first impression of the event below:

Honestly, my impression was a lot more high-end, a lot cleaner, a lot more organized, a lot more "how can I help you". It was a ton more designer. It hadn't even occurred to me that there would be furniture and electronics and sheets and stuff like that. I was just thinking that little boutique section but blown up into this big, beautiful area. And we got there and it was pretty humbling. (Danielle)

Kristen, a self-proclaimed "power shopper" likes the Rummage Sale because she was able to get a lot of the things she needed for her new house:

I was closing on a new house that I'd bought two weeks after Rummage Sale. So I bought just about everything I needed. I was starting over from a divorce. So I had no furniture. I bought a few clothing items for myself. I bought several handbags, because I always love the handbag section, and a bunch of clothes for kids. And my son's teacher has an infant, a little girl, and I have 2 boys, so I raided the little girls' section. (Kristen)

The variety and organization of the merchandise at the Rummage Sale matched up with Kristen's needs. While this research focuses on the purchase of clothing at the Rummage Sale, many participants mentioned buying other merchandise at the event as well. Utilitarian purchasers appreciated being able to purchase things for themselves, their homes, and their families all in one setting. 


\section{Motivation for Donation}

\section{Hedonic Donating_Feel-Good Donors}

Just as some individuals purchased for emotional reasons, some individuals donated to fulfill emotional needs. Thus, these respondents were categorized as feel-good donors.

For example, when asked about donating clothing to the organization, Anita stated,

I feel like I did a good thing. And, in my mind, I am imagining someone less fortunate wearing my clothes. (Anita)

From Anita's quote, we get the sense that donating clothing to the Rummage Sale uplifts her spirit because she imagines that her clothes are going to help the less fortunate members of her community.

Similarly, Fran mentioned,

But I mean I feel good, because I think it's great that somebody can get something.... I think that's great. Because I think stuff's overpriced anyway. I want people to be able to clothe their children. And adults, too. (Fran)

Likewise, Kristen is also a feel-good donor who considers donations of her unwanted items in terms of what they will be used for in the future. "I feel good. I'm willing to give my stuff away as long as I know it's for a good cause and people will use it and appreciate it" (Kristen). Emotional feelings and a concern for how and what will happen to their clothing was common. The notion of clothing having a purpose and being used by someone else was prevalent in all of the feel-good donors. Despite the fact that the donors 
have no control over who actually will receive their second-hand clothing after donating it, donating for these hedonic donors is a pleasurable experience because they imagine that they are helping others in their community by doing so.

It seems to be the case that some members of the Junior League have not had much interaction with those who have a real financial need to purchase second-hand clothing. Seeing these individuals at the Rummage Sale seemed to solidify the notion that their donations were going to a good cause, and this made these hedonic donors feel good about their actions. According to Nicole,

Well, for one, you have to, because you have to have your quota. But it is a good service for the community. And I'm sure you noticed working in ladies this year...I am amazed, having never had dealings with.... The first day of the sale, and these people came in, and they were just so thankful that they could get this clothing. And people were talking about spending their whole budget for the year for the kids' clothes or their grandkids' Christmas presents. Yeah, I mean, I'm happy to do that. (Nicole)

For other members, the ability to help others now represents a chance to give back to those who helped them in the past. Not all Junior League members started out in the upper socio-economic class. Donating reminds Piper of perhaps a not-so-pleasurable time from her past. By donating now, Piper experiences positive emotions when she has the chance to help others out now. As Piper states,

We used to live in Pennsylvania, and we didn't have a lot of money. So we shopped at Goodwill. So we've been through that time when we needed nice and kind-of trendy things and we couldn't afford it, so we would go to Goodwill. So it's like we are giving back to it now. (Piper) 
For some respondents, their donations made them feel an additional layer of positive emotions because they are able to help both the organization of which they are members as well as the members of their community. Even though Julie stressed the fact that she felt obligated to donate to the Rummage Sale because she was responsible for planning the event within the Junior League organization, she still mentioned that she felt good about being able to help other people with her donation efforts. According to Julie,

I now pretty much only donate to the Rummage Sale because, like I said, I am about to be in charge of it.... There's certainly a lot of good clothing causes out there. I try not to put anything in the trash unless it's men's t-shirts with holes in it and it's dirty and it's got stains and it's gross. I put that in the trash or make it into a car rag. I mean, most of the clothing I buy, I would like to think at least the nicer clothing would hold up.... I love what the Rummage Sale does. Obviously, I believe in its mission providing that service to the community. (Julie)

According to Ellie, she collects items all year long to donate. However, she saves the best things for the Rummage Sale donation because "the money goes to a good cause and I know where it is going. It's an organization that I am involved in" (Ellie).

For Sam, supporting the organization she belongs to make her feel good. So she is indirectly supporting others through the support of the organization.

Well, I donate because I certainly want to support the League. And the donations are crucial to the success of the Rummage Sale because if we don't have good quality donations...I mean, that is really how we are making our money.... But it feels good because I am supporting a group that I feel very strongly about. (Sam)

Interestingly, while these women did mention helping others via their clothing donations, they did not mention helping the environment by donating clothing. This does not imply that they did not care about protecting the earth's natural resources. Instead, it 
seems to suggest that these women had a present-time focus with their donations. They wanted to help individuals who were having financial difficulties at the present time rather then helping individuals who will live on the planet in the future. In this sense, they are more worried about those in need now instead of those in need in the future.

Not all donors did so to experience positive emotions. Some individuals donated primarily to obtain a less cluttered home. While they may have been satisfied with their donation behavior and feel good about the outcomes related to donating clothing to the Rummage Sale, the process they used to collect their donations was much more organized and planned out and far less emotional. These respondents were categorized as utilitarian donors, and they are discussed below.

\section{Utilitarian Donating-Methodical Donors}

Just as individuals purchased in a utilitarian manner, they also donated in a utilitarian manner. Utilitarian donors did not have an emotional response to donating. When they deemed it necessary, they would donate. Because these respondents had developed somewhat objective criteria for donating, and, in some cases very elaborate techniques for removing unwanted items from their active clothing rotation, these individuals were categorized as methodical donors.

Four of the participants were characterized as methodical donors, which is less than a quarter of the total. One reason why respondents indicated that they donated was because of a lack of space in their closets. For many, a changing of the seasons meant that clothes from the spring and summer would be replaced by clothes from the fall and winter in their closets. Rachel noted that she finds clothes to donate relating to this 
timing. "It can be when I come across something but mainly when I switch the closets"

(Rachel). She continues describing how she removes clothes seasonally:

So every season when I put my clothes away for that season, I kind of look through... and even for my husband, when I make him donate for Rummage Sale...I look through what have I not worn. Why did I not wear it? Did I ever go to it and go, "Oh, no." Mainly it's for fit, if it's something I haven't worn and I realize that I haven't worn it for the past few seasons, then I start moving it to the room over my garage which is where I keep all my Rummage Sale donations for the year. So I separate it out and hang it on a rolling rack there to keep it ready. (Rachel)

Rachel has a separate location for her unwanted items. This behavior is very rational and utilitarian.

Gwynne continuously removes unwanted items from her closet. Although she did indicate that cleaning her closet made her experience positive emotions, these emotions were inner-directed, rather than outer-directed. Gwynne stated,

I feel good about it because it's cleaning junk out of my house. I am not a packrat. I don't like to keep a lot of stuff that's not needed at our house. So I feel good to clean out and make room for new things. (Gwynne)

Here, Gwynne mentions that donating does make her feel good. But, while the hedonic donors are feeling good because they are helping other people by donating their clothing, Gwynne is feeling good about herself because her donating behavior is helping her have a clean, organized house that she desires. In fact, Gwynne is so interested in organizing and having a clutter-free home that she has developed a system for continuously donating unwanted clothing: 
I have a bag in a closet that's there all the time. And if I put something on and it's not fitting good or I feel like the color has faded, or the cotton is getting kind of nubby and it's not soft, and it doesn't look good anymore, I'll just toss it into that bag and it goes to Rummage Sale. (Gwynne)

While Gwynne describes donating unwanted clothing as a continuous process, Claire describes donating for a specific instance. Claire moved to a new house which motivated her to go through her closet and remove unwanted items. When the Junior League made it too difficult, Claire donated somewhere else. She donated them to Goodwill for the ease and convenience. She did not donate her clothes to the Rummage Sale because that would have required her to store the clothes for several months, something she was not willing to do. "So all of my clothes went to Goodwill. I wasn't going to pay to store them and to move them" (Claire).

Claire does care about what will happen to her clothes and indicates that she does not like to throw clothes away. When asked if she ever throws clothes away, she replied, "I try to give them to someone else. If they're in good shape I try to give them away. Like underwear always goes in the trash" (Claire). While giving clothes away can be viewed as a hedonic act, Claire does not seem to participate in clothing donation as a way to feel good. She is mainly utilitarian in her actions of giving unwanted clothing away. She wants to donate her clothing to other people, whether through the Rummage Sale or less formal channels, because it helps her achieve her goal of clearing out her home. 


\section{Factors Influencing Motivation for Donating}

\section{Demographic Characteristics}

Age. For the most part, the respondents for this study tended to be hedonic donors. Therefore, it was more difficult to identify demographic characteristics that were related to hedonic donation motivation. The four utilitarian donors, however, did tend to share some characteristics, such as age. All of the utilitarian donors in this study were in their late-twenties or early-thirties. At this stage in life, many young women are working hard to achieve success in their careers. Additionally, many women are in committed relationships with significant others and are thinking about getting married or have already been married. All but one of the utilitarian donors was married. As these young women attempt to balance their professional and personal lives, they may feel pressure to be organized. As a result, they may have a process for several activities that they engage in, including donation behavior. To manage their busy lives, these women must have exceptional time management skills and develop a method to handle the madness.

Gwynne, who not only works full-time outside of the home but also is raising two children, indicated that she was not a fan of the Rummage Sale because it is so demanding on her busy schedule. As she stated,

It's the hours, and to commit to an entire week. Because I work during the day and then to have to go straight to Rummage Sale. I just miss out on time with my kids and it's hard for my husband, doing the little kid thing by himself all week. (Gwynne) 
As this quote illustrates, Gwynne is an extremely busy person. Perhaps having a plan to follow in terms of donations makes the task easier and allows her to be prepared when the Rummage Sale rolls around each year.

For some of the utilitarian donors, the time commitment and efficiency of the fund-raiser causes concern. Claire, who has been participating in the Junior League for several years, feels that the Rummage Sale uses too many resources for the amount of money that is actually earned by the event. She explained:

We don't make a lot of money for the amount of hours and amount of hours that goes into it. I mean the amount of money we spend just trying to put the fundraiser on...kind-of...it's just ineffective. When you are looking at women... two three-hour shifts, a five-hour shift, and a four-hour shift...that's fifteen hours a week. (Claire)

All of the utilitarian donors have full-time jobs in addition to many other responsibilities. These participants can be described as being "time poor," so it makes sense that participating in the Rummage Sale is not for personal enjoyment but rather another responsibility to be met. While many of the hedonic donors also work full-time, the hedonic donors tended to be younger than 25 or older than 35 . Perhaps at this stage in their lives, the hedonic donors were experiencing greater feelings of altruism.

\section{Social Psychological Characteristics}

Clothing Attachment. Hedonic donors tended to have a stronger attachment to their clothing than did utilitarian donors. One way this attachment became evident was through their rich descriptions of their clothing, particularly their favorite pieces of clothing. 
For many hedonic donors, it seemed to be difficult for them to part with their clothing, even if they were no longer regularly using it. Hannah admitted to having clothing in active storage that she no longer wore or cared for. She said,

I hold onto my clothes so long. I have clothes in my attic that I wore when I was in college in the 1960s, so it's really hard for me to let go. Because then you hold onto it long enough and it becomes vintage. But what I try to do is, every season when I'm moving my winter clothes out or whatever, I'll try to get rid of the things that I absolutely resist wearing and because I just don't love it. (Hannah)

Lauren, who actually seemed to be a utilitarian purchaser, was attached to her

favorite piece of clothing. She related a story about losing one of her favorite dresses:

I have this one dress, I'm so irritated because I lost it somehow. I know I took it to the beach, and I don't know if I left it at the beach. We have a condo that we share with other people, and it was not there when I came back. Or if I took it to the cleaners...I made the cleaners go through and look at everything! I cannot find this dress, but I loved it! It was Trina Turk. It was v-neck. It had really great colors, and a fun design. I just loved the way it fit. (Lauren)

We can sense with this quote that Lauren is upset that she cannot find this dress any longer, suggesting that she is attached to it. Lauren, like Hannah, also mentions that she has trouble discarding clothing that she no longer wears.

I did give a lot of my own clothes to Rummage Sale. I don't know...I do feel like I hold onto stuff for a long time. Even if I haven't worn it. I definitely have stuff in my closet that I have not worn in 2 or 3 years. I don't know why I keep it, but I do! (Lauren) 
When Nicole talks about her favorite piece of clothing, she describes a situation in which she purchased it impulsively. She describes several details about the dress. She became excited when talking about it:

The best thing I have right now is this dress that I bought at Target. Now I didn't go in looking for the dress. I went in looking for something else specific, but happened to see it. And it's a Target dress and cost $\$ 20$, but it's so flexible and so versatile. It's a little denim dress. It has a flower appliqué on it and you can dress it up or dress it down. And it's easy to pack and we've been travelling a lot, so that's my favorite piece. (Nicole)

Nicole also has trouble getting rid of unwanted items. She actually appreciates the Rummage Sale because it forces her to go through her closet and discard items. As she stated,

And that's the thing, I think if I didn't have Rummage Sale, my closet would probably be full of old things. By the time I decide to give something away, it is probably past the point of taking it to a consignment store and getting anything out of it because it is probably out of date or whatever. If it's just one or two or three things, that's just not worth my time to try to do that. So Rummage Sale is a great way excuse for me to try to meet my quota and go in and say, "Yes, I can get rid of this. I can let that go." That's very helpful to me to purge the closet. Otherwise I think it would sit there a lot longer than it does. (Nicole)

For Nicole and several of the other hedonic donors, parting with clothes is something that is hard to do but they acknowledge the need to get rid of clothes. The Rummage Sale is an opportunity for the participants who have formed strong attachments to clothes to try to let go of those attachments. It is safe to say that without the Rummage Sale the donors with particularly strong attachments to their clothes would not engage in the process as often. This is in contrast to the following donors. 
Voluntary Simplification. The utilitarian donors tended to have simplified lives. As a member of the Junior League, donation of items is strongly encouraged. However, the items donated to the Rummage Sale do not have to be clothing items. The donation process is based on an honor system, meaning that no one actually checks each individual's donations. All except one of the participants indicated that they had unwanted items that they were willing to donate to the event each year. When asked if she ever had trouble finding enough items to donate, Lauren stated, "I might have right after I got married and I didn't have kids and stuff. But my oldest is 7, so with the toys and books, I can always find plenty of stuff" (Lauren).

Even participants who were not married or did not have children did not seem to have a problem. Piper commented, "It was definitely easy. I think we needed to have 60 items. It was so easy. My parents had stuff, too, and actually their friends had stuff, too" (Piper). Because clothing is not the only category of merchandise available for sale at the Rummage Sale. As a result, members are usually able to come up with the amount of donations for the event without much problem.

Ivy was the only participant who indicated difficulty in having enough unwanted items to donate to the event every year:

I give everything to Rummage Sale because I don't really have.... As I said, this is my third Rummage. And my first Rummage, I was moving from our house in Ardmore to our house we have now. And I purged everything that I didn't want in the new house basically. And that all went to Rummage. So I had this huge pile of Rummage and it took forever to sort. And then we got to the new house and I really didn't have anything. Unless it's... you know.... I don't buy just lots and lots of stuff. I buy, like, selectively, so I don't end up with a bunch of stuff after the course of a year, just like stuff I don't like. So I didn't really have anything the 
second year except for all the stuff the people we had bought the house from had left in the closets. They just left things in closets and left things in drawers. And I have a storage, cubby place upstairs that I put everything in for Rummage. I just lugged it all out of there and put it in there so that was my Rummage the second year. And this year I didn't have anything. Except that my mother-in-law gave me a bunch of clothes from a friend of hers who is my same size, but obviously she's a lot older than I am. And so, even though they fit, it wasn't necessarily something... you know.... I don't want high waisted pants with pleats down the front from Talbots. I'm just not going to wear them. So basically, that was my Rummage. And now I don't know what I am going to do next year for Rummage honestly. (Ivy)

Ivy expressed the fact that she is a very specific purchaser so she does not have much unwanted clothing every year. So, although Ivy enjoys the experience of shopping at the Rummage Sale and is classified as a hedonic purchaser, she is very organized when it comes to donating. She does not seem to be as attached to clothing and is willing to discard things she knows she does not want, like the clothing that was gifted to her.

Connection between Motivations and Factors Influencing Motivations

\section{Hedonic Purchasers and Donors-Treat Seekers}

Treat seekers are characterized as those individuals who were both hedonic purchasers and donors. For the respondents who were consistent in terms of their motivations for purchasing from and donating to the Rummage Sale, connections could be identified between the factors that influenced their motivations for purchasing and donating.

In terms of demographic characteristics, the youngest and the oldest respondents were categorized as both hedonic purchasers and donors. These individuals presumably had the most free time to shop, not just at the Rummage Sale but at all other times and 
places, as well. These individuals had the least amount of professional and personal obligations. And, because they have the most free time to shop, they also tended to acquire the greatest number of clothing items. Piper, one of the youngest interviewees, mentioned that, even though she has three closets for her clothing, she does run out of storage space. According to Piper,

When I can no longer fit anything into my closet, which does happen.... I have three closets right now. It's like the trendy stuff that I haven't worn in a very long time. But normally when I don't have any hangers left, I know I need to take some stuff out. Like if I haven't worn this in like a year, then I know it needs to come out. (Piper)

Piper does not seem to want to discard clothing unless it is absolutely necessary. In her case, the necessity arises when she has no additional storage room for new additions to her wardrobe.

Conversely, Mary, who is one of the oldest interviewees, discussed how she had many things to donate because she has had a great deal of time to collect things. Mary stated, "For example, I have stuff to give because I am 50. Whereas you, as twentysomething, you don't have so much. Or you might, but it's probably at your mom's or dad's or not" (Mary).

In terms of social psychological characteristics, the hedonic purchasers and donors tended to have a high need for uniqueness coupled with a strong attachment to clothing. While shopping, hedonic purchasers and donors wanted to be unique and did not mind spending time looking for those unique items. After they introduced the items they purchased into their wardrobes, they became attached to their clothes and had a 
difficult time giving them up. The hedonic purchasers and donors may have had trouble discarding their clothing because they were displaying their individuality, creativity, and personality with their clothing. Thus, they might have felt like they were giving up a part of themselves when they discarded clothing.

Anita, for example, does not like to part with her clothing. She has a system to make sure that she does not accidentally give away clothing that she claims that she "loves." Anita stated,

Yeah, and then if there is something that I'm on the fence about, I'll try to keep it. Like, recently, when I went through my clothes, there were some things that, when I moved nine months ago, I thought, "I'm going to wait." But then, this time, I was like, “O.K. I didn't wear this in the past nine months." And then I got rid of it. So, I'll give myself a trial period. And I'll be like, if I don't wear this in.... And then the next time I go through, it's like gone. (Anita)

Danielle, another hedonic purchaser and donor, also has trouble discarding clothing because she is attached to those items and experiences positive emotional reactions when thinking about them:

I had this blue dress, and I wore it one night. And we were out in Chapel Hill, and I got a lot of compliments on it. It doesn't look good anymore. It's falling apart. It doesn't fit $100 \%$ right. It's not that expensive. I will not get rid of it. I won't wear it, but it will sit there until the end of time. (Danielle)

So, even though it is no longer functional, Danielle refuses to part with particular clothing items that she is attached to. Many of the hedonic purchasers and donors mentioned having difficulty managing their wardrobe. Relating back to the Winakor (1969) "bath tub" model of clothing consumption, these participants tended to wait until 
they have an overflow of supply of clothing before taking action to manage it. This is in contrast to the next group of participants.

Utilitarian Purchasers and Donors-Planners

There were only two individuals who were utilitarian purchasers and donors. They exhibited a very high degree of organization in their consumption and donation behavior which is why they are referred to as planners. They were both in their earlythirties and were married and worked full-time. While one of these interviewees had children, the other interviewee did not. However, it may be the case that these two individuals are simply the most organized women who participated in the study. Thus, these two women may be similar in terms of their personalities. Plus, they are not as attached to their clothing as others, so they do not have a difficult time discarding unwanted apparel.

Interestingly, these two women seemed to be the most disappointed with the Rummage Sale and they seemed to have the most animosity towards the Rummage Sale. Claire said,

I really hate the Rummage Sale. The reason I don't like the Rummage Sale is because I feel like it is a really ineffective fundraiser. It's a terrible fundraiser.... You're looking at all these women putting in fifteen hours a week at minimum wage. That's $\$ 7.65$ right now. But you look at that, and you multiply it out, and you look at what we make. And, I mean, really, how many of us are really going to go for minimum wage anyway? You look at that alone and there's got to be a more effective fundraiser. (Claire) 
This quote from Claire illustrates that she is a very methodical person. She is focused on the amount of time and energy that goes into the event. Such rational thinking makes Claire the most utilitarian of all the participants.

Gwynne complained about the small number of donations this year compared to other years in the past.

I felt like this year for the first time it didn't seem as strong as far as the amount of donations. The hype and the build-up for it was just kind-of weaker this year. Overall, I don't really know why. It's just kind-of a consensus among my friends, too. When we started the sale, we were like, "Oh my gosh. These boxes aren't even full." Normally we have extra boxes underneath the tables ready to top when they are empty. And we didn't even need to do that this year. It was just kind-of different. (Gwynne)

Gwynne seemed to be having trouble understanding why the donations were lower this year. She may feel that others should be more organized with their donations so they have more to give to the Rummage Sale.

\section{Hedonic Purchasers and Utilitarian Donors-Reward Seekers}

There were two women who were hedonic purchasers and utilitarian donors. Both of these participants appear to be internally focused. Their consumption behaviors and their donation behavior are rather self-serving and for this reason they are referred to as reward seekers. The common demographic characteristics that these two women shared were the fact that they were young and married but did not have kids. Because of these characteristics, these women probably have more free time to shop because they do not have children to care for. But they still have to keep an organized house because they have to take care of their husbands. 
In terms of social psychological characteristics, these two women enjoyed shopping. They seemed to use shopping as a pleasure-seeking behavior and a hobby. But neither one of these women became attached to their clothing.

As Ivy mentioned, she loves to shop. But she also says, "No, I'm not very attached to physical things or material things. So if it's at a point where I'm ready to get rid of it, I just give it to Goodwill because I don't have a lot of Rummage” (Ivy).

Rachel discussed how she liked to shop for fun with her family on the weekends.

I actually kind-of go shopping once a week. My mother and grandmother...we have an outing in Greensboro on Saturdays. So I go there.... I'm an only child, so we go to lunch and then we kind-of piddle around the Friendly Center area. We just roam around. (Rachel)

However, Rachel, unlike other hedonic purchasers who are hedonic donors, does not feel attached to the clothing that she purchases. So, it is not difficult for her to discard items. Rachel, who removes unwanted items throughout the year, keeps everything in a separate location, waiting for the next Rummage Sale. She said, "I try not to be too packratty" (Rachel).

Rachel is so organized and trying to maintain a simple life that she admits to not having enough to donate. "It's starting to get a little harder because I feel like I've purged more the past few years" (Rachel). These individuals discard clothing when it no longer serves a purpose for them. They do not really think about the impact of their donations but rather just removing the unwanted items from their closets. 


\section{Utilitarian Purchasers and Hedonic Donors—Rational Helpers}

The rational helpers wanted the clothing they purchased in a rational manner to go to a good cause. Most of these women had children. It may have been the case that these women previously liked to shop, but now, with their young families, they no longer had enough leisure time to shop recreationally. Most had strong attachments to the clothing they purchased, even if they tended to purchase it based on price. For some, they had strong attachments to their children's clothes as well as their own clothing. Lauren, who was very distraught that she lost her favorite dress, said,

I do have sentimental attachments to some of my children's clothes. So there are some things, but not as much as some people that I talked to that are my friends. There are some things that I will keep. Like I kept the dress they wore on their first birthday and stuff like that. (Lauren)

Nicole also has a hard time getting rid of things that are hers as well as her children's:

I have a hard time letting go of things for some reason. I don't know why. But it takes a while for me to decide, you know. It has to be completely out of date before I let go of it. Because there's a chance a might decide to wear it again.

Nicole saves her own clothes because she feels that she may one day want to wear them again. Nicole also saves her children's clothes but for a different reason. She goes on to describe her attachments to her children's clothes.

Oh yes. And much more for them than for me. Especially like you were saying, for the memories. I don't probably keep as much as some people do because boys don't have as many memorable things as girls do. Like the pretty little dresses. There's only so much you can do for boys, but like the things we brought them 
home from the hospital in and little things that they wore all the time when they were small and we just have good memories of. (Nicole)

Overall, Nicole and the other women in this group have some trouble getting rid of their clothes. The utilitarian purchasers and hedonic donors mentioned that the Rummage Sale actually forced them to get rid of their unwanted merchandise. Olivia mentioned that "usually Rummage Sale is an important reason why I go through" my wardrobe (Olivia). Nicole echoed this sentiment when she stated, "And that's the thing. I think if I didn't have Rummage Sale, my closet would be full of old things" (Nicole).

The women donated because they wanted the Rummage Sale to succeed and they acknowledged that their donations are an integral part of the success. They also acknowledged that donating their time to volunteering is important for the success of the Rummage Sale. None of the utilitarian purchasers and hedonic donors complained about working at the Rummage Sale. This may be because they were committed members of the organization. Most had been members for at least four years. Ellie said,

I love it. I'm not one of the girls who absolutely hates it. I'm glad it's a week and we don't have a Rummage Store that we have to donate time to. But for me, it's pretty painless, so I enjoyed it. I enjoy working with the girls in my department and getting to know them. It's almost better than doing something in the community, getting-to-know-them-wise, because you are out doing other things and the focus is on other things. I enjoy it. It is a time to socialize. (Ellie)

Sam mentioned her love of the Rummage Sale because of the social aspect:

I could see doing this indefinitely to help the Rummage Sale. But it gets harder as you get older because when you've been in it longer is when your friends start leaving and then there's a lot of people you don't know. So you start to feel old. But I enjoy it, so I don't mind. 
Julie said that she liked the Rummage Sale because she got to help people. This reinforces the reason why she donated in the first place, to help people.

I sold a girl her wedding dress. In the boutique section, we were standing there, and she had just had a baby, obviously, and was getting married to the baby's father. And it was a situation that was different from my own, just really was a sweet girl. And she didn't have any money but she wanted a wedding dress and wanted to feel pretty like everybody does when they get married. It was really sweet. (Julie)

\section{Additional Themes}

\section{Liminality}

While conducting the interviews, several themes emerged that were not necessarily related to women's purchasing and donating motivations but were important nonetheless. One of these was related to the concept of liminality. A person's possessions are a reflection of their personal identity. As people transition throughout their life, the type and style of their clothing can change to reflect this transition. The Rummage Sale appears to be a context in which participants purged their unwanted items from their previous life stage and purchased new items that more accurately reflect the stage that are entering.

Kristen is a recent divorcee who used the Rummage Sale as a way to acquire items for her new self and her new home. Through the process of her divorce, Kristen needed new things that would be used in her new home and would fit her new role as a single woman. 
Danielle's life stage is a single, recent college grad who is interested in expensive clothing. With a limited budget, she wants the experience without the higher price tag. Describing her favorite store to shop in, she states,

Actually I have a very specific one. It's my favorite retail/apparel/customer service all across the board. It's the Billy Read stores. I've been to the one in Nashville and New York City... But Billy Read if I want more of the experience. But I can only buy one thing at a time. (Danielle)

Her favorite store is one that she can't actually purchase clothes from very often. As Danielle has transitioned from a college student to working in a professional office, her clothing purchasing habits have shifted also. Danielle is able to find clothing that is appropriate for her new identity as a young professional at the Rummage Sale. However she expresses some guilt about shopping at the Rummage Sale.

I felt a little guilty that I wanted to come in and buy all of the designer castoff things that were, you know, a good find, for me. But for some of these people, it would have been huge. Whereas I can talk myself into a Kate Spade dress, a lot of the people shopping there couldn't. It just wouldn't have been an option. I did feel a little guilt, but I felt a lot better about being there are volunteering. (Danielle)

Danielle is interested in helping others but concerned for her own future. The Rummage Sale appears to be a win-win situation for Danielle because she is able to acquire some clothing that enables her to express her new role in life as well as volunteer her time and help others.

Recently having a baby, Ellie now appreciates second-hand items and their lower price, especially with maternity clothes and baby items. Ellie's family structure changed recently, with the addition of a child. She is also no longer working full-time outside of 
the home. These life transitions have led to a need for more and different clothing items. Ellie's perception of second-hand items has become more favorable during these life transitions.

I used to not like it. I used to just like to take tags off stuff. But after having a baby and having my body change so quickly, it's just not really worth my while. So even with second-hand toys and stuff I get. But when he was born everything was new but now it's like, because he goes through stuff so fast. So yeah, I like the concept. (Ellie)

While talking about what they donated to and what they purchased from the Rummage Sale, several of the participants began talking about the transitional period in the lives they were currently undergoing. These transitions included changes in marital status, family size, and life status. This reflects the idea that people want their possessions to be a reflection of themselves, and when their life situation changes, so too must their possessions.

\section{The Impact of Organizational Involvement}

Most of the participants indicated that meeting new people and being involved in the community was their greatest motivation for joining the Junior League. Julie describes her personal experience for joining:

Right when I graduated from Wake Forest I was going to work for Wake Forest about 5 months after graduation. I realized that if I don't meet some people from this town that aren't from Wake Forest it's going to be harder to live here. It was going to be my only bubble. And the Junior League gave me other people to meet and socialize with and it definitely made Winston Salem a little more homey. Because I'm not from here. So that was kind of nice. And I love the Rummage Sale for that. Because it's a week when everyone's together. And even though we are complaining about somebody throwing out dirty socks, it is a lot of fun. (Julie) 
It appears that most members joined the service organization for social reasons.

Danielle, a first year member, gave a candid explanation of how she feels about joining the Junior League:

After having been at Meredith and having a women network with an all girls school, I wondered if it would be the same vibe. And it is most of the time. And it was the same thing at Meredith where I was sometimes freaked out by it. You know, too many women in one place, too many smiles, I don't remember your name, a little exhausting. But,you know, at the end of the day, I really like the message and everyone can get excited about women this and women that, and I like that. (Danielle)

Olivia, who was asked by her employer to join as a way to promote the jewelry store she works in, had a different approach:

So I came in, and they were like "We're always wanted someone to join the Junior League. We'll pay your dues, anything" Now when I took a board position last year I kind-of cut back on that. I didn't really feel like it was fair for every time I go and sit in a three-hour meeting, because I chose to sit on the board. . . So that's how it started, but I do think it is a great organization. Being involved in the community and being on the board, and running all the community, especially with all the women's health placements this year, it's interesting to see a whole different segment of Winston Salem. (Olivia)

The role that Olivia plays in the Junior League shifted once she joined. At first she was there almost as a work obligation but she has enjoyed the organization and has become much more involved by taking on leadership positions.

The notion of joining initially for social reasons but then transitioning into a greater level of involvement and leadership roles was common. Several of the members who have been in the League for a longer amount of time indicated that the community impact was the greatest motivation for them. Sam stated, 
I joined the Junior League probably more as a social.... Just to get to know people but also to give back to the community. It seemed like a really structured organization, one that could actually use me well and I could do as much or as little as I wanted. And I've done that over the years. Some years I've been really, really busy on committees. And then other years I haven't had quite as much to do, which has worked out because maybe I was pregnant or really busy with my real job. So I've really liked that. And I've gotten to know a lot of really great people. I loved being on the Rummage Sale committee. That was one of my favorite committees because I love that so much. (Sam)

Fran also mentioned the social aspects as being important to her. But she stressed the impact on the community and the specific needs that are met by the organization:

And I think the Junior League as an organization is just a fantastic organization because they give back to so many different parts of our community. And I totally believe in Winston Salem and our community. I think it's an awesome place to be. And it wouldn't be such a great place without organizations like the Junior League. And I really like where we are going with the League and helping children and families and women's health issues. So I like being a part of that group. And I like, too, that it helps women foster their development and find leadership qualities. So, all in all, I think it's a great organization. (Fran)

\section{Summary}

In this chapter, a thematic interpretation of the data was presented. The participants were categorized based on their responses in the interviews. Chapter Five presents additional discussion about the motivations of second-hand clothing purchase and donation. 


\section{CHAPTER V \\ DISCUSSION AND IMPLICATIONS}

This chapter includes the following sections: (a) discussion of relative findings in support of the study objectives and (b) limitations of this research and suggestions for future research.

\section{Research Objectives}

The objectives of this study included:

1) To explore second-hand clothing consumers' motivations (e.g., hedonic, utilitarian) for purchasing clothing from the retail outlet associated with one particular charitable organization (i.e., Junior League Rummage Sale).

2) To examine the demographic (e.g., age, income, marital status) and social psychological factors (e.g., eco-consciousness, need for uniqueness, price consciousness) that may have an impact on consumers' motivations for purchasing second-hand clothing from the retail outlet associated with one particular charitable organization (i.e., Junior League Rummage Sale).

3) To uncover second-hand clothing consumers' motivations (e.g., hedonic, utilitarian) for donating clothing to the retail outlet associated with one particular charitable organization (i.e., Junior League Rummage Sale).

4) To investigate the demographic (e.g., age, income, marital status) and social 
psychological factors (e.g., eco-consciousness, need for uniqueness, price consciousness) that may have an impact on consumers' motivations for donating clothing to the retail outlet associated with one particular charitable organization (i.e., Junior League Rummage Sale).

5) To identify the relationships that exist, if any, between second-hand clothing consumers' motivations (e.g., hedonic, utilitarian) for purchasing from and donating to the retail outlet associated with one particular charitable organization (i.e., Junior League Rummage Sale).

6) To explore the relationships that exist, if any, between the factors (i.e., demographic and social psychological) that influence second-hand consumers' motivations (e.g., hedonic, utilitarian) for purchasing from and donating to the retail outlet associated with one particular charitable organization (i.e., Junior League Rummage Sale).

\section{Second-hand Clothing Purchasers}

\section{Similarities in Hedonic Purchasers' Motivations}

With respect to the first objective, evidence existed from the interviews to suggest that the women purchased clothing for themselves as well as their family members either hedonically or in a utilitarian fashion at the Rummage Sale. Those women who were categorized as hedonic purchasers mentioned that shopping at the Rummage Sale was a fun, social experience. In this way, the interviewees' comments support the work of Badin et al. (1994) who found that hedonic purchasers tend to shop 
with others and to enjoy the social interactions while shopping. Some of the hedonic participants shop with other friends and family members in order to get feedback before making second-hand clothing purchases. Anita fits this description because she wanted to ask her friends' opinions before purchasing clothing to make sure that the clothing looked good on her.

The hedonic women also discussed the enjoyment they felt when they spent time searching through the various departments at the Rummage Sale to find a treasure. The hedonic purchasers often came to the event without preconceived notions about what they were looking for. Belle was an example of this type of shopper because she frequently shops in second-hand stores just to see what is available. The inability to know what merchandise will be available is a positive feature for the hedonic shoppers. These shoppers also like to find unique items. It appears that the process is as enjoyable if not more enjoyable than the actual product acquisition. This relates to the "thrill of the hunt" experience wherein the experience of finding something is actually just as much fun as what is found. This supports the work of Bardhi and Arnould (2005), who found that hedonic shoppers in thrift stores appreciated the thrill of the hunt.

Many of the hedonic shoppers were brand-conscious. Brand names can be a way to gage the quality and fit of a garment. For this reason, several participants indicated the brand of the clothing that they purchased from the event. For example, Fran clearly remembers that she purchased a Diane von Furstenberg dress. Some participants mentioned looking at the brand name tag because it helped them to know what size they were. It made the shoppers more comfortable to buy a brand that they recognized and had 
purchased before. Other participants indicated that they look for high-end designer names that they would otherwise not purchase at full retail price. Finding a high-end brand name at an extremely discounted price was mentioned as a favorite aspect of second-hand shopping for the hedonic shoppers.

Individuals who care more deeply about their clothing are more likely to experience contamination issues, either positive or negative. Roux and Korchia (2006) describe the concept of second-hand clothing contamination as occurring through the transference of meaning from one owner to the next. Stains from perspiration or odor are physical proof of markings left from a previous owner and present, but psychological meaning can also be transferred. Handing down clothing from a relative or a close friend can be viewed as a powerful way to stay connected to that person. This was true in the participants' interviews. Ivy and Belle, who were both hedonic purchasers, describe positive contamination with second-hand clothing. Ivy refers to purchasing a secondhand fur stole. The initials of the previous owner have been sewn into the fur. Ivy described the idea of it being worn by someone else as exciting. "I do like that is has a story, that it was someone else's. They probably loved it" (Ivy).

Impulse or unplanned purchasing was common in the hedonic shoppers. The participants were not as focused on planning or organizing their shopping trips, like utilitarian shoppers.

\section{Similarities in Utilitarian Purchasers' Motivations}

The utilitarian purchasers at the Rummage Sale discussed looking for and purchasing specific clothing items. They tended to have a shopping list in mind when 
they shopped at the event. In addition, they did not deviate very much from their list. They did not enjoy browsing aimlessly through the departments. They had a certain goal in mind, and they were most satisfied with their time spent shopping at the Rummage Sale if they were able to locate and purchase the items off of their mental list. In this way, the findings support the research on utilitarian shopping by Badin et al. (1994).

Additionally, utilitarian purchasers indicated that they liked to shop alone at the Rummage Sale, which also supports the work Badin et al. (1994). Perhaps the utilitarian purchasers believed that shopping with others would slow them down or make the accomplishment of their purchasing goals more difficult. Therefore, shopping alone was preferable for these goal-oriented purchasers.

Interestingly, at the Rummage Sale, or any other second-hand clothing store, one never knows exactly what will be in the store when one goes shopping. Second-hand clothing stores have a very different retail merchandising strategy than clothing stores that sell new clothing. While the new stores may stock multiples of the same item or several similar items, second-hand clothing stores typically have only one of each item. Therefore, when individuals plan to purchase a specific item of clothing at a second-hand store, their requirements for this item must obviously be a little more lenient than their requirements for items they may purchase at new clothing stores. While at a clothing store that sells new clothing, utilitarian purchasers could develop a more specific list and a more developed mental picture of their desired items (e.g., tan Dockers pants with straight legs and a cuff in size 12), perhaps only a few characteristics of the desired products (e.g., product category, color, size) can be identified prior to visiting second- 
hand clothing outlets. If utilitarian purchasers attempt to make a very specific list prior to visiting the second-hand clothing store, they undoubtedly face disappointment if they are unable to locate this item during their shopping trip. Some of the utilitarian purchasers acknowledged the need to have somewhat flexible shopping criteria, such as looking for a product category like "clothing for work," instead of a specific item. Future researchers could investigate which product characteristics are among the most important to utilitarian purchasers or the ways in which utilitarian purchasers plan their trips to second-hand clothing stores.

\section{Demographic and Social Psychological Similarities of Hedonic Purchasers}

The women who were categorized as hedonic or utilitarian did share some demographic and social psychological characteristics with their category members. Identification of these similarities addressed the second objective of the study. Women who shopped hedonically at the Rummage Sale tended to be among the oldest and the youngest members of the sample. This finding supports the previous work of Reilly and DeLong (2011), who found that second-hand clothing purchasers tended to be young adults, and Guiot and Roux (2010), who found that hedonic purchasers in second-hand stores tended to be older adults. The women may have not had as many commitments in terms of employment outside of the home and family obligations. The youngest women did not have children yet, and the oldest women's children were grown and generally took care of themselves. Thus, these women perhaps had more time to spend engaging in their own pursuits. For this group of women, one of their favorite pursuits was shopping. In this respect, the Rummage Sale provided them with an opportunity to do something 
they loved, so it would be expected that they would be hedonic purchasers at the Rummage Sale.

Another similarity shared by these women was a need for uniqueness. The hedonic purchasers appreciated the chance the Rummage Sale provided to them to find clothing that no other person they knew would have. The need for uniqueness among second-hand clothing purchasers was found by Reiley and DeLong (2011). Additionally, Guiot and Roux (2010) found that hedonic purchasers in second-hand stores tended to have a need for uniqueness. Therefore, the current study supported their findings.

Along these same lines, several hedonic purchasers tended to be creative individuals. They used the clothing or other items they purchased at the Rummage Sale in new ways. Although they repurposed the items, none of the women, hedonic or otherwise, mentioned that purchasing was related to being eco-friendly. Despite the fact that purchasing second-hand clothing has often been associated with the environmentally conscious movement (Dickson, 2000), this did not seem to be the driver for these women, even the ones who did repurpose. Instead, they seemed to want to remake items to express their creativity or unique style.

\section{Demographic and Social Psychological Similarities of Utilitarian Purchasers}

On the other hand, utilitarian purchasers tended to be different from hedonic purchasers both demographically and with respect to social psychological characteristics. Unlike the hedonic purchasers, the utilitarian purchasers at the Rummage Sale tended to have young, elementary school aged children at home. The majority of these women also had full-time employment outside of the home. With all of these responsibilities, these 
women did not have as much leisure time, perhaps, as the hedonic purchasers. And, with the limited amount of leisure time these women did have, they chose not to engage in shopping as their pastime. This is not to suggest that all utilitarian purchasers necessarily disliked shopping, in general, or shopping at the Rummage Sale, in particular. From the statements made by these women in the interviews, it seemed to be the case that these women were busy and, as a result, needed to be organized in order to complete their required tasks.

Being busy and raising a family may have an impact on the social psychological characteristics that seemed to be influencing these women's utilitarian fashion of purchasing at the Rummage Sale. These women tended to be price conscious, which was also found in previous research conducted by Guiot and Roux (2010), and expressed a need for convenience while shopping. Having to feed and clothe several individuals can be expensive, even if one has a decent annual salary. Any time that utilitarian purchasers can save money, they appreciate it. The Rummage Sale definitely offers these women such an opportunity. They can purchase high-end items for a low cost for both themselves as well as the other members of their families. This is not to say that hedonic purchasers do not like to save money. Instead, this simply suggests that saving money is more important to utilitarian purchasers than hedonic purchasers at the Rummage Sale.

In addition to saving money, saving time is also important to utilitarian purchasers. Hence, these women felt positively about the physical layout and organization of the Rummage Sale. The department organization helped them save time and accomplish their tasks quickly, which satisfied their need for convenience while shopping. 


\section{Second-hand Clothing Donors}

\section{Similarities in Hedonic Donors' Motivations}

With the third and fourth objectives, the focus is turned to donating behavior. Evidence from the interviews suggested that women donated to the Rummage Sale hedonically and in a utilitarian manner. The women who donated clothing hedonically to the Rummage Sale did so because it made them feel good to donate. They believed that they were helping out less fortunate women and families by donating their cast-off clothing. They imagined that these individuals were purchasing the second-hand clothing for an affordable price, and, in this way, the hedonic donors were able to experience pleasurable feelings through their donation behavior. In this way, the findings from this current study support the work of Ha-Brookshire and Hodges (2009).

Although some of the hedonic donors mentioned specific instances when they helped needy people purchase clothing at the Rummage Sale, the truth is that they do not have control over who purchases their cast-off clothing after they donate it. Due to the fact that the Rummage Sale is open for the general public, it is possible that wealthy women or families who have no need to purchase inexpensive second-hand clothing are actually the recipients of the donations. Furthermore, given that members of the Junior League do purchase second-hand clothing at the Rummage Sale and most of the members of the Junior League do not have a financial need to do so, there is a high likelihood that the best donations may actually be purchased by those who do not have a financial need. Some of the interviewees actually complained about this situation. Thus, there seemed to be an awareness of the fact that the donated clothing might not be purchased by the 
neediest individuals. Regardless of the reality of the situation, the donors did so out of the goodness of their heart and the action made them feel good. As a result, they were donating in a hedonic fashion.

It is interesting to note that, although many participants recognized the ways in which their donations helped people in the community, they did not seem to recognize a similar benefit from their own purchasing behavior at the Rummage Sale. The money that is generated by the purchases of products at the Rummage Sale is donated back into the community because the proceeds are used to support additional programs hosted by the Junior League (e.g., Child Abuse Puppet Show, My Aunt's House). For the most part, the women in the Junior League did not have a financial need to purchase clothing at the Rummage Sale. However, when thinking about the people who did have a financial need to purchase inexpensive clothing, the interviewees did recognize the fact that their donations of clothing made the purchase of their second-hand clothing possible. In this way, the effect on the community is direct through the community members' purchases but indirect through their own purchases in the sense that they, themselves, have no financial need to purchase the clothing available at the Rummage Sale. Because secondhand clothing stores need both donors and purchasers to be successful (Bendapudi et al., 1996), future researchers could explore ways in which to convert donors to purchasers and vice versa.

\section{Similarities in Utilitarian Donors' Motivations}

While the majority of the respondents were hedonic donors, a few of the women were more utilitarian in their approach to donations to the Rummage Sale. These women 
were extremely organized and had developed a method for selecting and storing donations they wanted to make to the Rummage Sale each year. Because these women donated their clothing primarily to rid their closets and homes of unwanted goods, this finding supports the work of Ha-Brookshire and Hodges (2009), who also found that some individuals donated clothing to acquire more space in their closets.

One difference between the donors in Ha-Brookshire and Hodges' (2009) study and the donors in the current study was the number of utilitarian donors. Perhaps the reason why there were more hedonic donors than utilitarian donors in the current study was due to the fact that the women interviewed were members of the Junior League, the organization which was responsible for planning and executing the Rummage Sale. Because the women being interviewed had a strong relationship with the organization, this may have had an impact on the motivations for their donations to this particular organization (Bendapudi et al., 1996). It may be the case that when the members of the Junior League donate clothing and household items to other organizations, such as the Goodwill or Salvation Army, they do not feel as much of an attachment to the other charitable organizations. As such, they may not experience an emotional reaction when donating items to these organizations to the same degree that they do when making donations to the Junior League. This possibility can be explored further in future research.

Demographic and Social Psychological Similarities of Hedonic Donors

Similarities in the demographic and social psychological characteristics of hedonic donors were identified in the current study. Due to the fact that a significant 
majority of the sample donated hedonically, differences were not particularly abundant. However, age seemed to be one of the most important demographic characteristics. While the age of hedonic donors varied, the oldest and youngest interviewees were hedonic donors. This supports previous research which suggests that, as people age, they tend to become more altruistic (Solomon, 2004). Additionally, the youngest members of the sample were a part of Gen Y, and these individuals tend to also be altruistic as well (Solomon, 2004).

The hedonic donors were much more attached to their clothing items and had a more difficult time parting with them. Anita described a dress that is too small for her but she will not get rid of. She explained, "Because I don't feel comfortable giving it away because I love it. And it's so nice. And I want to save it for someone that I feel is deserving" (Anita). As a hedonic purchaser and hedonic donor, Anita feels a close connection to the clothing she owns and has trouble parting with her clothes. Perhaps the hedonic donors were more attached to their clothing because they were using those apparel items to express their individuality and creativity in a way that utilitarian donors did not seem to be.

Demographic and Social Psychological Similarities of Utilitarian Donors

Some similarities in the demographic and social psychological characteristics of the utilitarian donors were identified in the current study as well. The two utilitarian donors were in their late-twenties or early-thirties. This is a time when women are busy with their careers and starting their own families. These women may have felt a need to be organized in order to make their lives simpler. The notion of simplifying life came 
across in the utilitarian donors' responses. Unlike the hedonic donors, the utilitarian donors seemed to have a need for simplification. The utilitarian donors were willing to part with items much more easily than the hedonic donors.

Again, like the purchase of second-hand clothing, previous researchers (Bianchi \& Birtwistle, 2010) found that individuals donated clothing to charitable organizations for ecological reasons. By donating clothing, individuals who care about protecting the environment can keep their clothing out of landfills. No donors, utilitarian or hedonic, in the current study mentioned the environmental impact of their donation behavior. This does not imply that these individuals do not care about protecting the environment. Instead, their donation behavior is influenced predominantly by other factors.

Relationship between Motivations and Factors Influencing Motivations The fifth and sixth objectives of the current study addressed the relationships that exist between the motivations for purchase and donation as well as the relationships that exist between the factors that influence those motivations. In terms of the relationship between the motivations for purchasing and donating to the Rummage Sale, some patterns did emerge. As Figure 1 illustrates, the majority of the participants were either hedonic purchasers/hedonic donors or utilitarian purchasers/hedonic donors.

Additionally, almost every woman in the study was hedonic in either her purchasing or donating behavior or both at the Rummage Sale. For the women in the current study, there seemed to be an interest in clothing and shopping for clothing. Most of the women seemed to be attached to their clothing, which made donating clothing 
difficult for them.

Figure 5. Hedonic and Utilitarian Categorization and Age of Participants.

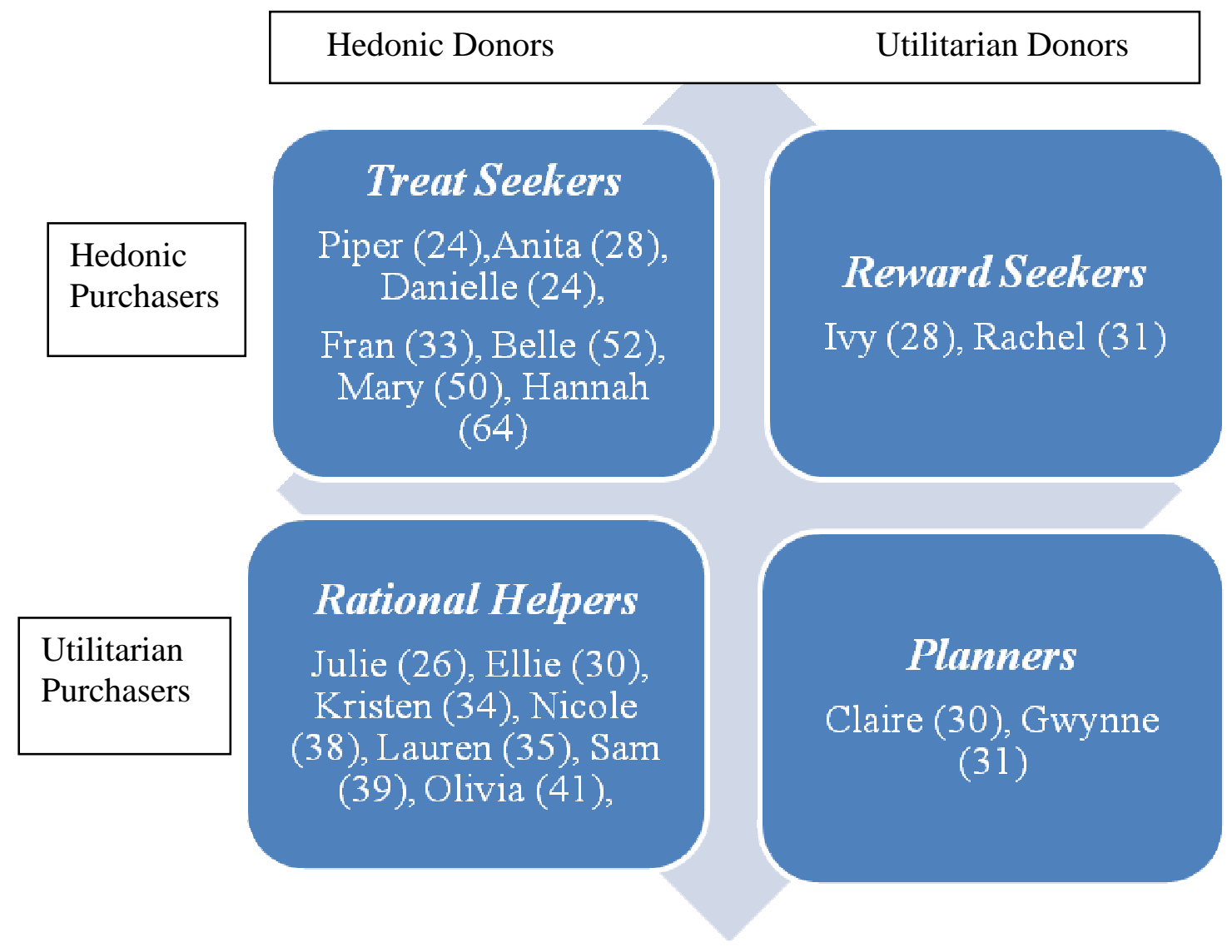

Similarly, the majority of the women in the study enjoyed shopping and were hedonic purchasers at the Rummage Sale. It also seemed to be the case that many of the women in the study who were classified as utilitarian purchasers and hedonic donors previously enjoyed shopping. Because their current situation with young children at home and full-time employment outside of the home required many of them to now be utilitarian purchasers, they seemed to have developed into utilitarian purchasers over time. It may be the case that these women, especially those who were previously more 
hedonic in their approach to shopping when they were younger, will develop into more hedonic purchasers as they age.

The least amount of respondents were categorized as utilitarian purchasers and utilitarian donors. For these women, organization seemed to be the driving force behind all of their behavior with respect to the Rummage Sale. These women appreciated the organization of the Rummage Sale, itself, because they felt a need for convenience while shopping for and purchasing clothing. The busy lives of these women demanded that they also be organized at home to successfully accomplish all of the tasks they planned for each day.

While reading the responses of these women, one does not sense that they ever were hedonic in the approach to shopping. It seems unlikely that these women will ever become hedonic purchasers at the Rummage Sale as they grow older. Perhaps the reason why there were so few utilitarian purchasers and donors in the current study was due to the fact that individuals who were contacted to participate but who did not enjoy purchasing from or donating to the Rummage Sale did not feel compelled to participate in the study. In other words, the utilitarian purchasers/utilitarian donors tended to choose not to participate. It may also be the case that there were more hedonic purchasers and hedonic donors because this study focused on women and clothing. Women tend to be more hedonic than men and clothing is considered a hedonic product category (Solomon, 2004). Although their study focused on mainly purchasing behavior, Albinsson and Perera (2009) found that the emotional aspects associated with hedonic donating seems to be a feminine characteristic. Furthermore, women tend to be more involved with 
clothing. If a different product category, such as electronics, were under investigation, the women may have been categorized differently.

One word of caution is needed with respect to the interpretations. While being exclusively hedonic or utilitarian in purchasing behavior is possible, it is more often that a presence of both aspects in present within an individual's recounting of a shopping trip. A sort of continuum can be used with a person being placed at some point on the continuum and can therefore be categorized as being more hedonic or utilitarian based on looking at all of the responses. This type of "shades of grey" rather than "black and white" has been mentioned in other types of research on this subject (Teller, et al., 2008).

\section{Additional Findings}

\section{Liminality}

While attempting to accomplish the objectives of the study, additional themes emerged that were unexpected. One of these themes related to liminality. Both purchasing and donating have been associated with liminality. The ways in which consumers behave have been shown to be affected by a life transition (Andreasen, 1984). Similarly, the desire to donate certain items related to a previous life situation has been uncovered in previous research. Although it was not anticipated that these issues would be addressed by participants in the current study, several individuals did mention that as a reason for purchasing and donating. The women who experienced transitions were hedonic donors. Because this is the first study, it is not known whether this is just a 
coincidence or if this represents a true pattern. Future researchers could continue to investigate this relationship.

\section{Managerial Implications and Impact on Junior League}

By definition, participants in a service organization are asked to volunteer their time and resources to the cause. For the Junior League, there are many different types of volunteer opportunities as well as opportunities for socializing with other members as well as other members of the community. The differing levels of involvement and individual members' reactions to their involvement were captured in the interviews.

It appears that most of the members initially joined the organization for social reasons but have stayed because they believe in the organization. All of the participants felt supportive of the mission behind the Junior League but some had some concerns about the way the Rummage Sale was run and managed. Charitable organizations face many of the same issues and competition as other retailers. Specifically, those that rely on second-hand donations in order to have merchandise to sell face the difficulty of attracting two types of transactions, those of the donors and those of the purchasers.

Since most of the members view the Junior League as both a service-based organization and a social experience, it is important that the Rummage Sale is marketed as both a service project and a social event. Managing the volunteers in a way that satisfies both of these conditions for members could increase the satisfaction level of members, thus improving their overall participation and experience.

This research marks one of the first times that donation behavior and purchase behavior was investigated in the same context. By better understanding the motivations 
of those who purchase from and donate to a charitable organization, managers may be able to attract and retain customers as well as attract high quality donations.

\section{Limitations and Future Research}

This research has several limitations that could be addressed in future research on second-hand clothing donation and purchase. First, all of the participants were females that were involved with a particular service organization. Secondly, this research was designed to investigate voluntary purchase and donation behaviors. However, a obligation of the organization is to participate in the event and to provide donations.

Due to the fact that all of the participants were females from one service organization, the findings may not necessarily be generalized to other populations. Being in a service organization can mean (a) higher income, (b) more time to help others, (c) more interest in helping others (empathetic). The similarity in the demographical information collected from the participants is another reason why the findings may not be generalized to other populations. It does add to the literature that states that like-minded people will be drawn together.

Additionally, the researcher is also a member of this service organization. However, the researcher does not hold a leadership position and made sure participants did not feel any obligation to the researcher. As a fellow member of the service organization, the participants may have been more likely to agree to the interviews. Many members were asked to participate but only those that fit the criteria were selected. It is possible that the members who responded also felt more inclined to help out. The 
participants who agreed were proportionately more involved in the service organization (e.g., president, finance chair, Rummage Sale chair and other committee members). Members who were less involved with the service organization may not be as willing to participate in a research study as other more involved members. This could be another inadvertent limitation to the sample that was selected.

One of expectations for being in the Junior League was to donate items to the event. Therefore, this behavior is not completely voluntary. All of the participants indicated that they donate their unwanted clothes to the Rummage Sale even though the organization does not require clothes as donations. Other donations are acceptable like furniture, books, and electronics. It did not appear to be an inconvenience for the participants to donate clothing; all but one participant indicated having more than enough excess clothing to donate.

Another concern stems from the fact that participants were asked to recall their experiences with second-hand clothing donation and purchase, so biases in responses could be present. Interviews took place between two and three months after the event. Hopefully the responses were not affected by the break in time between the actual behavior and the interviews. "Shadowing" participants or conducting interviews immediately following may be advisable to eliminate this type of issue in the future.

With this research, an attempt was made to identify the motivations of individuals who purchased clothing from and donated clothing to the same charitable organization. The hedonic and utilitarian framework was useful for categorizing the women from the Junior League who participated in the study. For the Junior League of Winston-Salem, 
the Rummage Sale is an event that lasts only one week. Other Junior League chapters, including the Junior League of Greensboro, operate stores that are open year-round. In this way, these stores are more similar to the thrift stores operated by other charitable organizations, including the Goodwill and the Salvation Army. Researchers who are interested in identifying connections between donors and purchasers of clothing could repeat this study with a sample of individuals from a different charitable organization to see if the findings from this current study are applicable in other settings.

Furthermore, the current study focused primarily on clothing. Many other product categories can be purchased from and donated to charitable organizations. Researchers interested in the topic could compare the findings from the current study about clothing with findings from future studies about other product categories.

The current study utilized a qualitative methodology as a beginning stage to explore the relationships between purchase and donation behavior at the same location. The findings from the current study seem to support the findings from past endeavors utilizing a quantitative methodology and exploring purchase and donation behavior individually. The next step that could be taken would be to investigate purchase and donation behavior from the same location using a quantitative methodology. This would aid in the generalizability of the findings and may prove to be applicable for practitioners, like Goodwill Industries and other charity-based organizations, who serve many varying populations. 


\section{REFERENCES}

Albinsson, P.A. \& Perera, B.Y. (2009). From trash to treasure and beyond: The meaning of voluntary disposition. Journal of Consumer Behavior, 8, 340-353.

Allard, T., Babin, B. J., \& Chebat, J-C. (2009). When income matters: Customers evaluation of shopping malls' hedonic and utilitarian orientations. Journal of Retailing and Consumer Services, 16(1), 40-49.

American Apparel \& Footwear Association. (2009, August). An Annual Statistical Analysis of the U.S. Apparel \& Footwear Industries Annual 2008 Edition. Arlington, Va., 1-11.

Andreasen, A. (1984). Life status changes and changes in consumer preferences and satisfaction. Journal of Consumer Research, 11(3), 784-794

Arnold, M. J., \& Reynolds, K. E. (2003). Hedonic shopping motivations. Journal of Retailing, 79(2), 77-95.

Bayton, J. A. (1958). Motivation, cognition, learning: Basic factors in consumer behavior. Journal of Marketing, 22(3), 282-289.

Babin, B., Darden, W., \& Griffin, M. (1994). Work and/or fun. Measuring hedonic and utilitarian shopping values. Journal of Consumer Research 20(4), 645-655.

Bardhi, F. \&Arnould, E.J. (2005). Thrift shopping: Combining utilitarian thrift and hedonic treat benefits. Journal of Consumer Behaviour, 4(4), 223-233.

Bendapudi, N., Singh, S.N., \& Bendapudi, V. (1996). Enhancing helping behavior: An integrative framework for promotion planning. Journal of Marketing, 60, 33-49.

Bianchi, C. \& Birtwistle, G. (2010). Sell, give away, or donate: An exploratory study of fashion clothing disposal behavior in two countries. The International Review of Retail, Distribution, and Consumer Research, 20(3), 353-368.

Birtwistle, G., \& Moore, C. M. (2007). Fashion clothing-Where does it all end up? International Journal of Retail \& Distribution Management, 35(3), 210-216.

Carpenter, J. (2008). Consumer shopping value, satisfaction, and loyalty in discount retailing. Journal of Retail and Consumer Services. 15(5), 358-363. 
Carpenter, J. \& Moore, M. (2009). Utilitarian and hedonic shopping value in the US discount sector. Journal of Retail and Consumer Services. 16(1), 68-74.

Chang, E., Burns, L. D., \& Francis, S. K. (2004). Gender differences in the dimensional structure of apparel shopping satisfaction among Korean consumers: The role of hedonic shopping value. Clothing and Textile Research Journal, 22(2), 185-199.

Chantelat, P. \& Vignal, B. (2005). Intermediation is used goods markets: Transactions, confidence, and social interaction. Sociologie du travail, 47, 71-88.

Cicolini, Alice. (2005). Vintage Fashion. Encyclopedia of Clothing and Fashion. Ed. Valerie Steele. Vol. 3. Detroit: Charles Scribner's Sons. 398-400.

Cruz, S. (2010). Thrift Stores Get Facelift in Midst of Popularity. Retrieved from http://www.fox 40.com/news/headlines/ktxl-news-goodwillshoppingdecember8,0,6512765.story

Darley, W. K. \& Lim, J-S. (1999). Effects of store image attitude toward secondhand stores on shopping frequency and distance traveled. International Journal of Retail and Distribution Management, 27(8), 311-318.

Denegri-Knott, J. \& Molesworth, M. (2009). 'I'll sell this and I'll buy them that': eBay and the management of possessions as stock. Journal of Consumer Behaviour, 8 , $305-315$.

Dickson, M. (2000). Personal values, beliefs, knowledge, and attitudes relating to intentions to purchase apparel from socially responsible businesses. Clothing and Textiles Research Journal, 18(1), 19-30.

Diep, V., Sweeney, J. (2008). Shopping trip value: Do stores and products matter? Journal of Retailing and Consumer Service, 15(5), 399-409.

Engel, J. E., Blackwell, R. D., \& Miniard, P. W. (1995). Consumer Behavior ( $8^{\text {th }}$ Ed.). Chicago, IL: The Dryden Press.

Farr, R. M. (1996). The roots of modern social psychology. Malden: Blackwell Publishing.

Fitzwater, L. (2005). History of Secondhand Clothes. Encyclopedia of Clothing and Fashion. Ed. Valerie Steele. Vol. 3. Detroit: Charles Scribner's Sons. 
Gogoi, P. (2005, February 14). I am woman, hear me shop. Bloomberg Businessweek [Online]. Retrieved November 6, 2011, from http://www.businessweek.com /bwdaily/dnflash/feb2005/nf20050214_9413_db_082.htm

Guiot, D. \& Roux, D. (2010). A second-hand shoppers' motivation scale: Antecedents, consequences, and implications for retailers. Journal of Retailing, 86(4), 355371.

Ha-Brookshire, J. E. \& Hodges, N. N. (2009). Socially responsible consumer behavior? Exploring used clothing donation behavior. Clothing and Textiles Research Journal, 27(3), 179-196.

Hansen, K. T. (2005). Anthropology of Secondhand Clothes. Encyclopedia of Clothing and Fashion. Ed. Valerie Steele. Vol. 3. Detroit: Charles Scribner's Sons.

Hanson, J. W. (1980). A proposed paradigm for consumer product disposition processes. The Journal of Consumer Affairs, 14(1), 49-67.

Hibbert, S. A., Horne, S., \& Tagg, S. (2005). Charity retailers in competition for merchandise: Examining how consumers dispose of used goods. Journal of Business Research, 58, 819-828.

Holloway, W., \& Jefferson, T. (2000). Doing qualitative research differently: Free association, narrative and the interview method. London, UK: Sage Publications.

Jacoby, J., Berning, C. K., \& Dietvorst, T. F. (1977). What about disposition? Journal of Marketing, 41(2), 22-28.

James, S. L., Brown, R.B., Goodsell, T.L., \& Stovall, J. (2007). Thrift stores, and yard sales as middle-income survival strategies. Conference proceedings. American Sociological Association.

Jin, B., Chang, H. J., Matthews, D., \& Gupta, M. (accepted). Fast fashion business model: Why and how? In T.-M. Choi (Ed.), Fashion Supply Chain management: Industry and Business Analysis, Hershey, PA: IGI Global.

Kumar, S., \& Malegeant, P. (2006). Strategic alliance in a closed-loop supply chain: A case of manufacturer and eco-non-profit organization. Technovation, 26(10), 1127-1135.

Laio, S., Shen, Y., \& Chu, C. (2009). The effects of sales promotion strategy, product appeal, and consumer traits on reminder impulse buying. International Journal of Consumer Studies, 33(3), 274-284. 
Lastovicka, J.L. \& Fernandez, K.V. (2005). Three paths to disposition: The movement of meaningful possessions to strangers. Journal of Consumer Research, 31, 813-823.

Lee, M. \& Burns, L. D. (1993). Self-consciousness and clothing purchase criteria of Korean and United States college women. Clothing and Textiles Research Journal, 11(4), 32-40.

Lewin, K. (1951). Field theory in social science. New York: Harper \& Row.

Marshall, C., \& Rossman, G. B. (1999). Designing qualitative research ( $3^{\text {rd }}$ ed.). Thousand Oaks, CA: Sage.

Maycumber, S. G. (2008, July/August). Textile sustainability: More than just fiber-It's also how you deal with it. Textile Insight, 4(4), 6.

McCabe, D. B., Rosenbaum, M. S., \& Yurchisin, J. (2007). Perceived service quality and shopping motivations. Services Marketing Quarterly, 29(1), 1 - 21.

McCracken, G. (1986). Culture and consumption: A theoretical account of the structure and movement of the cultural meaning of consumer goods. Journal of Consumer Research, 13, 71-84.

McGoldrick, P. (2002). Retail marketing (2nd ed.). Maidenhead, Berkshire, UK: McGraw-Hill Publishers.

Mitchell, M., Montgomery, R., \& Rauch, D. (2009). Toward an understanding of thrift store donors. International Journal of Nonprofit and Voluntary Sector Marketing, $14,255-269$.

NARTS: The Association of Resale Professionals. (n.d.) Industry statistics and trends. Retrieved from http://www.narts.org/i4a/pages/index.cfm?pageid=3285.

Pachauri, M. (2002). Researching online consumer behavior: Current positions and future perspectives. Journal of Customer Behaviour, 1(2), 269-300.

Parsons, L. (2000). New goods, old records and second-hand suits: Charity shopping in South-West England. International Journal of Nonprofit and Voluntary Sector Marketing, 5(2), 141-151.

Patton, S-E. (2002). Qualitative research and evaluation methods $\left(3^{\text {rd }}\right.$ ed.). Thousand Oaks, CA: Sage.

Peters, T. (2003). Re-imagine! Business Excellence in a Disruptive Age. London, UK: Dorling, Kindersley Limited. 
Ratchford, B. T. (1987). New insights about the FCB grid. Journal of Advertising Research, 27, 24-38.

Reichheld, F. F. (1996). The loyalty effect: The hidden force behind growth, profits and lasting value. Boston, MA: Harvard Business School Press.

Reiley, K., \& DeLong, M. R. (2011). A consumer vision for sustainable fashion practice. Fashion Practice, 3(1), 63-84.

Roberts, J. (1995). Profiling levels of socially responsible consumer behavior: A cluster analytic approach and its implications for marketing. Journal of Marketing, 3(4), 97-116.

Rohm, A. J., \& Swaminathan, V. (2004). A typology of online shoppers based on shopping motivations. Journal of Business Research, 57, 748-757.

Ross, E. L. D., \& Iso-Ahola, S. E. (1991). Sightseeing tourists' motivation and satisfaction. Annals of Tourism Research, 18, 226-237.

Roux, D. \& Korchia, M. (2006). Am I what I wear? An exploratory study of symbolic meanings associated with secondhand clothing. Advances in Consumer Research, 33(1), 29-35.

Roux, D. \& Guiot, D. (2008). Measuring second-hand shopping motives, antecedents and consequences. Recherche et Applications en Marketing, 23(4), 63-94.

Rubin, H. L., \& Rubin, I. S. (1995). Qualitative Interviewing: The art of hearing data. Thousand Oaks, CA: Sage.

Rucker, M., McGee, K., Alves, B., Hopkins, M., Sypolt, T., \& Watada, M. (1995). Factors influencing consumer initiation of secondhand markets. European Advances in Consumer Research, 2, 425-429.

Ryan, T. (2009). Women's purchasing power grows. Retail Wire. Retrieved from http://www.retailwire.com/Email/Discussion.cfm/13569

Sandstrom, K. L., Martin, D. D., \& Fine, G. A. (2003). Symbols, selves, and social reality: A symbolic-interactionist approach to social psychology and sociology. Los Angeles, CA: Roxbury Publishing Company.

Scarpi, D. (2006). Fashion stores between fun and usefulness. Journal of Fashion Marketing and Management, 10(1), 7-24. 
Schouten, J. W. (1991). Selves in transition: Symbolic consumption in personal rites of passage and identity re-construction. Journal of Consumer Research, 17(March), 412-425.

Seidman, I. (1998). Interviewing as qualitative research: A guide for researchers in education and the social sciences ( $2^{\text {nd }}$ ed.). New York: Teachers College Press.

Seo, S. \& Lee, Y. (2008). Shopping values of clothing retailers perceived by consumers of different social classes. Journal of Retailing and Consumer Services, 15(6), 491-499.

Shim, J. (2010). IBIS world industry report: Used goods stores in the U.S. Retrieved from http://libproxy.uncg.edu:4148/industryus/default.aspx?indid=1101

Shim, S. (1995). Environmental and consumers' clothing disposal patterns: An exploratory study. Clothing and Textiles Research Journal 38(1), 38-44.

Solomon, M. R. (2004). Consumer Behavior: Buying, Having, and Being. ( $6^{\text {th }}$ ed.). Upper Saddle River, NJ: Pearson Prentice Hall.

Stone, G. P. (1954). City shoppers and urban identification: Observation on the social psychology of city life. American Journal of Sociology, 60(July), 36-45.

Strahilevitz, M. \& Myers, J.G. (1998). Donations to charity as purchase incentives: How well they work may depend on what you are trying to sell. Journal of Consumer Research, 24, 434-446.

Tauber, E. M. (1972). Why do people shop? Journal of Marketing, 36(4), 46-59.

Teller, C., Reutterer, T., \& Schnedlitz, P. (2008). Hedonic and utilitarian shopper types in evolved and created retail agglomerations. The International Review of Retail, Distribution, and Consumer Research, 18(3), 283-309.

Thomas, P. (n. d.). What is vintage fashion? Retrieved from http://www.fashionera.com/Vintage_fashion/1_what_is_vintage_fashion.htm.

To, P.-L., Liao, C., \& Lin, T.-H. (2007). Shopping motivations on Internet: A study based on utilitarian and hedonic value. Technovation, 27(12), 774-787.

Tortora, P. G., \& Eubank, K. (2009). Survey of historic costume (5 ${ }^{\text {th }}$ ed.). New York: Fairchild Publications.

Underhill, P. (2009) Why we buy. New York, NY: Simon and Schuster. 
Van de Velse, J., Pelton, W., Turnbull Caton, S., \& Byrne, M. (1996). Consumer behavior reflected in store and clothing selection criteria: A pilot study in Canada and England. Journal of Consumer Studies and Home Economics, 20, 371-391.

Wagner, T. (2007). Shopping motivation revised: A means-end chain analytical perspective. International Journal of Retail \& Distribution Management, 35(7), 569-582.

Watchravesringkan, K., Yurchisin, J., \& Padmanabhan, P. (2010). Predicting thrift store consumers' satisfaction and store loyalty: The role of store image attributes and corporate social responsibility. Proceedings of American Collegiate Retailing Association (ACRA) 2010 Spring Proceedings.

Westbrook, R.A., \& Black, W.C. (1985). A motivation-based shopper typology. Journal of Retailing, 61(1), 78-104.

Winakor, G. (1969). The process of clothing consumption. Journal of Home Economics, 61(8), 629-634.

Yavas, U. \& Riecken, G. (1981). Heavy, medium, light shoppers and nonshoppers of a used merchandise outlet. Journal of Business Research, 9, 243-253.

Yurchisin, J., \& Whitenack, K. (2007, November). From engagement to eBay: Why brides sell their wedding gowns on eBay. Paper presented at the annual meeting of the International Textiles and Apparel Association, Los Angeles, CA. 
APPENDIX A

INTERVIEW SCHEDULE 


\section{INTERVIEW SCHEDULE}

1. Was this your first year visiting the Junior League Rummage Sale? If so, how did it compare to your expectations of the sale before you went? If no, how many years have you visited the Rummage Sale? How did this year's sale compare to previous years' sales?

2. What made you decide to go to the sale this year? Did you go by yourself or with others? Why? Did you have any preconceived ideas about what you wanted to buy? What? Why? Did you end up buying that or something else? What? Why?

3. Tell me about what clothing you bought at this year's sale. What did you buy? How much did you spend? How did you decide what to buy?

4. In general, how do you know when you need to purchase some clothing? What makes you decide to go shopping and purchase clothing?

5. Describe your typical clothing shopping trip. Where do you go? How long do you spend shopping? How often do you shop for clothing each month?

6. Do you have a favorite brand or store? Why do you prefer that brand or store? How often do you visit that store to purchase clothing or purchase that brand of clothing? How much do you usually spend when you visit that store or purchase that brand?

7. Are there any clothing stores that you do not like? Which ones? Why not?

8. Do you set a clothing budget for yourself each year? Why or why not?

9. Describe your favorite piece of clothing. What is it? Why do you like it? How often do you typically wear it? Where or when would you wear it?

10. Thinking about that favorite piece of clothing that you just described, would you ever decide to part with it? Under what circumstances? When? Why or why not?

11. Describe your usual process for discarding unwanted clothing. How do you know that you should discard it? What do you usually do with it when you discard it? Why?

12. What did you donate to the Junior League Rummage Sale this year? Why? How did you decide to donate this? 
13. Have you donated to the Junior League Rummage Sale in the past? Did the amount or type of clothing you donated this year differ from the previous years' donations? Why?

14. Do you donate clothing to other organizations? Which ones? How often? Why or why not?

15. Do you donate other sorts of merchandise to the Junior League Rummage Sale or to other organizations? Which ones? How often? Why or why not?

16. Describe how you feel when you donate merchandise. Do you feel differently depending on the organization or type of merchandise? Why or why not?

17. What is your favorite aspect of donating clothing, in particular? Why? Least favorite? Why?

18. Do you purchase clothing from other stores selling second-hand clothing? Which ones? How often? Why or why not?

19. What is your favorite aspect of purchasing second-hand clothing? Least?

20. Do you shop alone or with other people when you purchase second-hand clothing? Why?

21. Describe how you feel when you purchase second-hand clothing. Why do you feel that way?

22. Do you purchase other sorts of second-hand merchandise at the Junior League Rummage Sale or from other organizations? Which ones? How often? Why or why not?

23. In general, what does the Junior League represent to you? What are some words that you might use to describe the Junior League? Why?

24. More specifically, what does the Junior League Rummage Sale represent to you? What are some words that you might use to describe the Junior League Rummage Sale? Why? Are these the same words that you would use to describe the Junior League in general? Why or why not?

25. Did you enjoy your experience at the Junior League Rummage Sale this year? Why or why not? What was your favorite part about the event? Least favorite part? 
APPENDIX B

DEMOGRPAHIC QUESTIONNAIRE 


\section{DEMOGRAPHIC QUESTIONNAIRE}

Please answer the following demographic questions.

1. Age: years

2. Ethnicity:

White/Caucasian

Hispanic/Latino(a)

Other (please specify:

3. Education level:

Less than high school High school graduate Some college

4. Marital status:

Married

Widowed

Domestic partnership
African-American Asian-American

College graduate Some graduate school Completed graduate school

Never married Divorced/Separated

5. Number of children under the age of 18 currently living with you

6. Personal annual income level:

Under $\$ 20,000$

$\$ 20,000$ to $\$ 39,999$

$\$ 40,000$ to $\$ 59,999$
$\$ 60,000$ to $\$ 79,999$

Over $\$ 80,000$ 
APPENDIX C

\section{CONSENT FORM}




\section{UNIVERSITY OF NORTH CAROLINA AT GREENSBORO}

\section{CONSENT TO ACT AS A HUMAN PARTICIPANT: LONG FORM}

Project Title: Comparing Donation and Consumption Practices of Used Clothing

Project Director: Dr. Jennifer Yurchisin (principal investigator) and Jennifer Baker (student researcher)

Participant's Name:

\section{What is the study about?}

This is a research project. The purpose of this research project is to investigate clothing donation habits as well as used clothing consumption habits.

Why are you asking me?

You are being asked to participate in this research project because you have indicated that you have both donated and purchased used clothing in the past 12 months.

\section{What will you ask me to do if I agree to be in the study?}

You will be asked to answer some questions about your experiences donating clothing and purchasing used clothing. There are no right or wrong answers to these questions. The approximate time to for the interview will less than one hour. If you have further questions about what is being asked of you for this research project, please contact Dr. Jennifer Yurchisin at (336) 334-5250 or jlyurchi@uncg.edu.

\section{Are there any audio/video recording?}

Yes. Your interview will be audio recorded. Because your voice will be potentially identifiable by anyone who hears the tape, your confidentiality for things you say on the tape cannot be guaranteed although the researcher will try to limit access to the tape as described below:

Your name will not be used to identify you but rather a code will be assigned to your audio recording. Once your interview is recorded the student research will transcribe your interview and no one else will listen to your audio recording.

Audio recordings will be kept password protected on the student researchers' computer and no one else will have access to them.

\section{What are the dangers to me?}

The Institutional Review Board at the University of North Carolina at Greensboro has determined that participation in this study poses minimal risk to participants.

If you have any concerns about your rights, how you are being treated or if you have questions, want more information or have suggestions, please contact Eric Allen in the Office of Research Compliance at UNCG at 
(336) 256-1482 Questions, concerns or complaints about this project or benefits or risks associated with being in this study can be answered by Dr. Jennifer Yurchisin who may be contacted at (336) 334-5250 or jlyurchi@uncg.edu.

Are there any benefits to me for taking part in this research study?

There are no direct benefits to participants in this study.

Are there any benefits to society as a result of me taking part in this research? This research may lead to a better understanding of the motivations of people who donate and purchase used clothing. A better understanding of such motivations may help researchers in the future.

Will I get paid for being in the study? Will it cost me anything?

There are no costs to you or payments made for participating in this study.

\section{How will you keep my information confidential?}

Your information will not be identified by name but rather your interview will be assigned a code name. The audiofiles with the code names will be kept password protected on the student researcher's computer. No one other than the principal investigator and student researcher will have access to the interviews. Any hardcopies of transcribed interviews will be stored in a locked file cabinet. All information obtained in this study is strictly confidential unless disclosure is required by law.

\section{What if I want to leave the study?}

You have the right to refuse to participate or to withdraw at any time, without penalty. If you do withdraw, it will not affect you in any way. If you choose to withdraw, you may request that any of your data which has been collected be destroyed unless it is in a deidentifiable state.

\section{What about new information/changes in the study?}

If significant new information relating to the study becomes available which may relate to your willingness to continue to participate, this information will be provided to you.

\section{Voluntary Consent by Participant:}

By signing this consent form you are agreeing that you have read it, or that it has been read to you and you fully understand the contents of this document and are openly willing to consent to take part in this study. All of your questions concerning this study have been answered. By signing this form, you are agreeing that you are 18 years of age or older and are agreeing to participate, or have the individual specified above as a participant participate, in this study described to you by Jennifer Baker.

Signature: Date: 